See discussions, stats, and author profiles for this publication at: https://www.researchgate.net/publication/300755060

\title{
Persönlichkeitsentwicklung an der Universität als zentrales Studienziel
}

\section{Chapter · April 2015}

DOI: 10.1007/978-3-658-09094-4_15

1 author:

Sabine Hoidn

University of St.Gallen

90 PUBLICATIONS 89 CITATIONS

SEE PROFILE

Some of the authors of this publication are also working on these related projects:

roject $\quad$ Video presentations View project

Project AERA-SIG Student-Centered Education (SCE) View project 


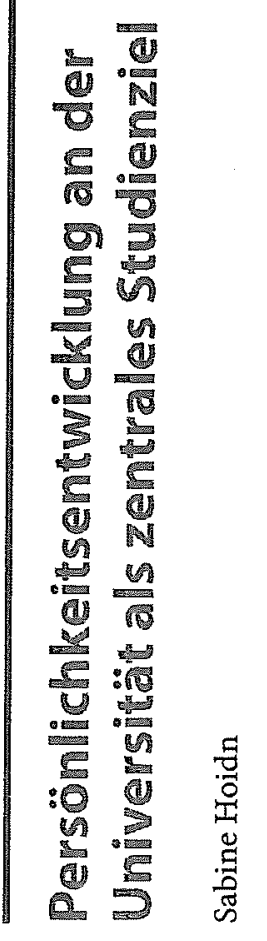

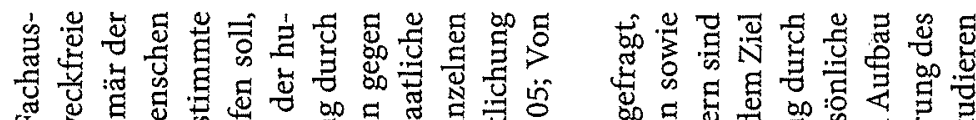

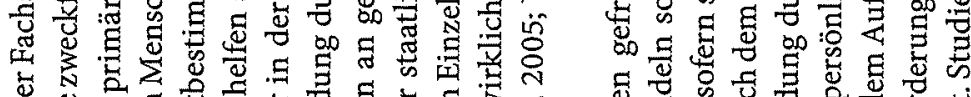

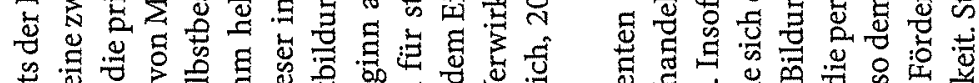

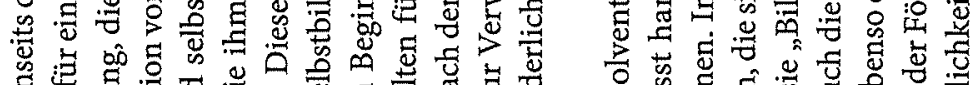

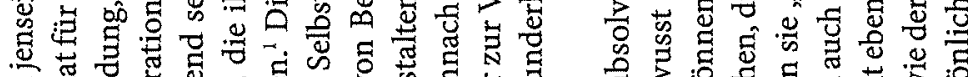

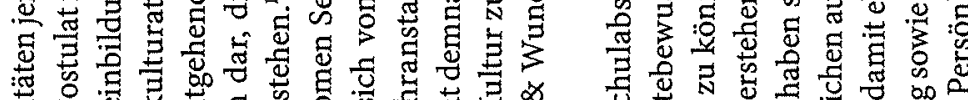

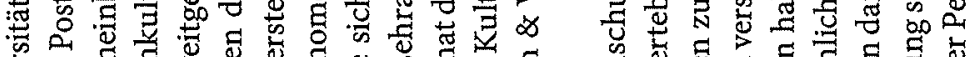

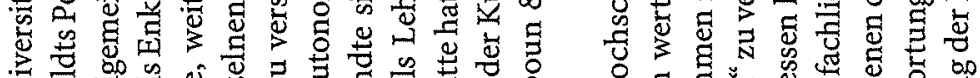

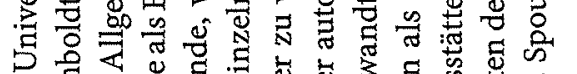

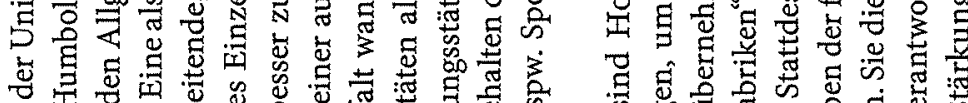

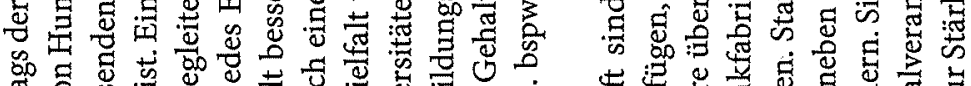

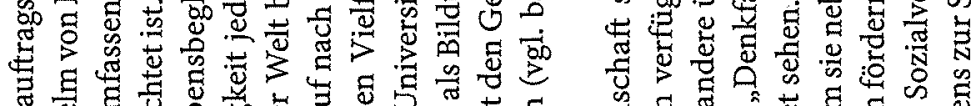

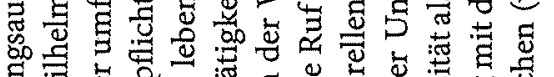

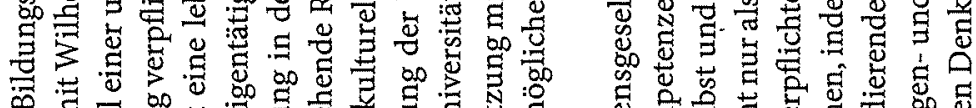
ह

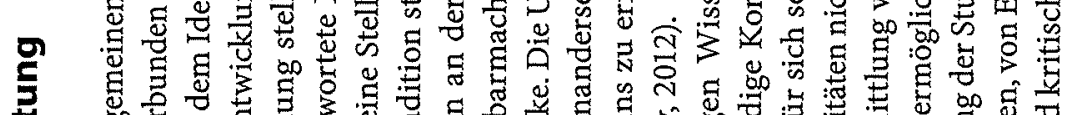

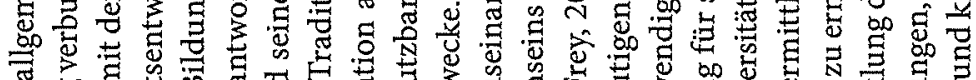

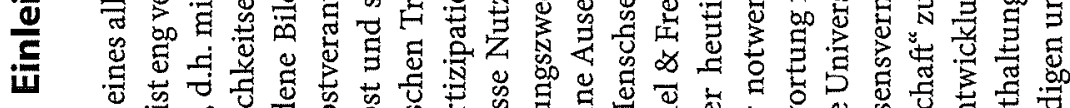

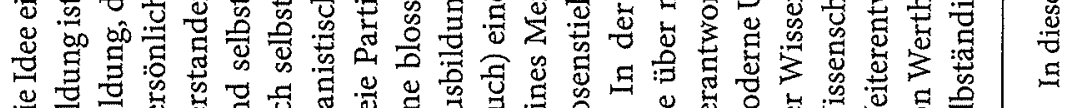

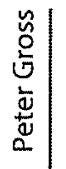

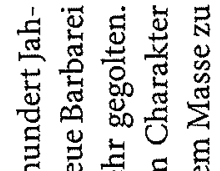

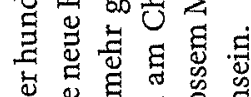
: 品

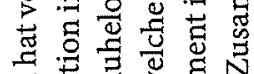

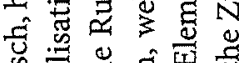

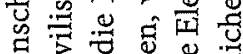

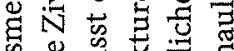

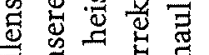

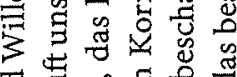

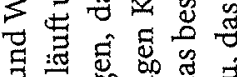

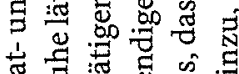

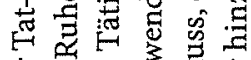

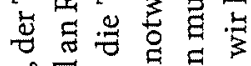

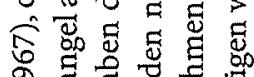

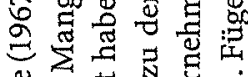

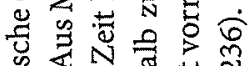
幽志矛焉

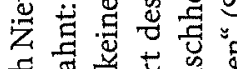

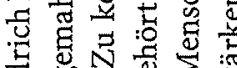

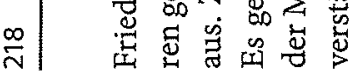

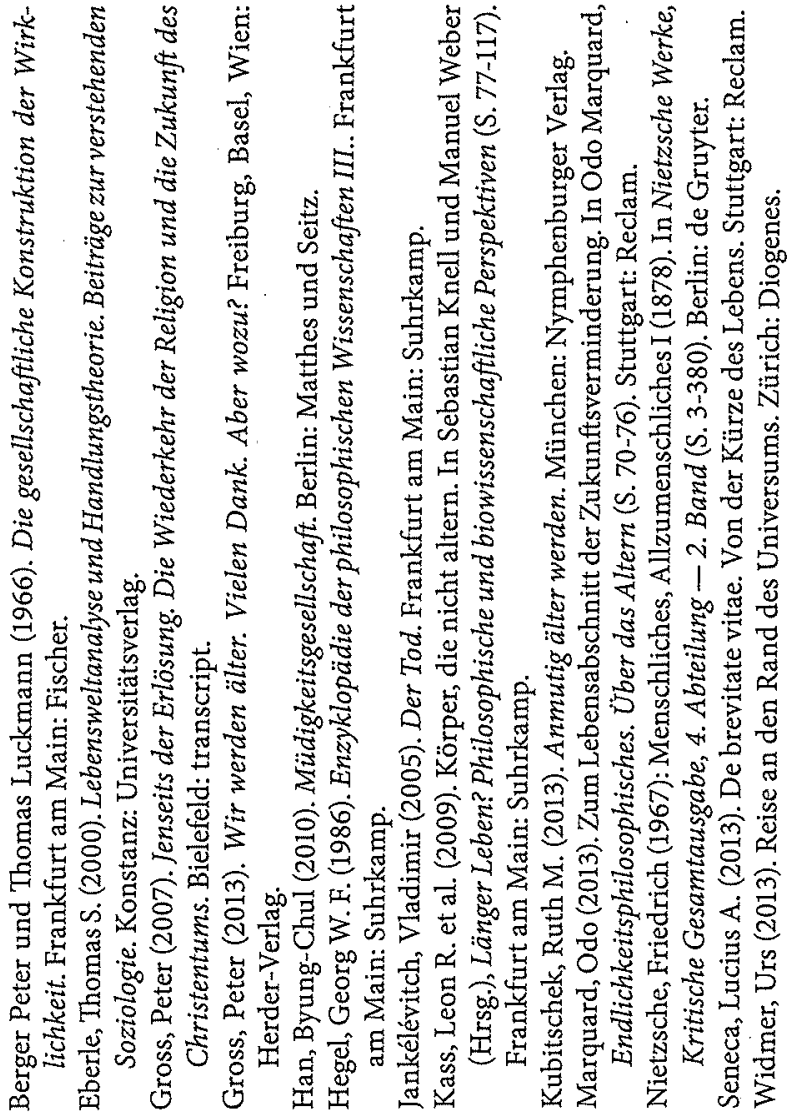




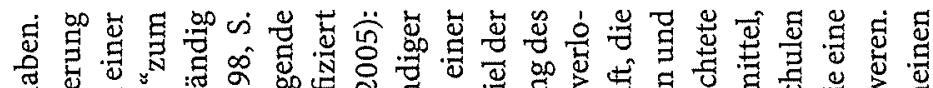

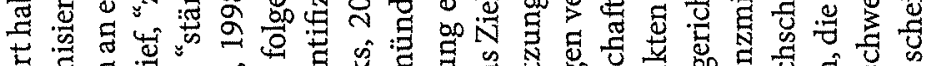

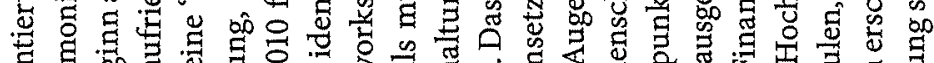

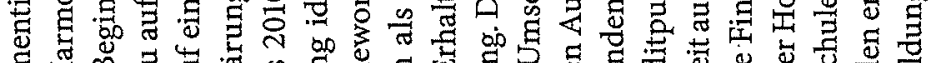

$\overline{\frac{\mathrm{u}}{N}}$

曾

$\frac{n}{\tilde{0}}$

空

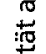

$\stackrel{\frac{2}{2}}{\frac{2}{c}}$

㐫

施

$\stackrel{\text { g }}{\frac{1}{3}}$

$\frac{\text { U. }}{3}$

产

$\frac{\underline{v}}{\mathrm{U}}$

竞

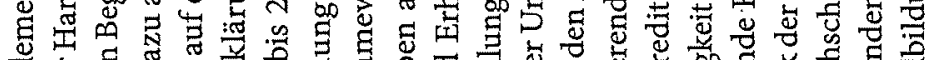

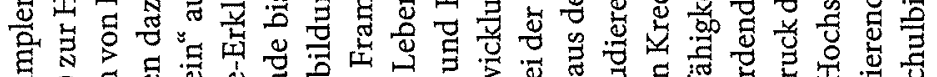

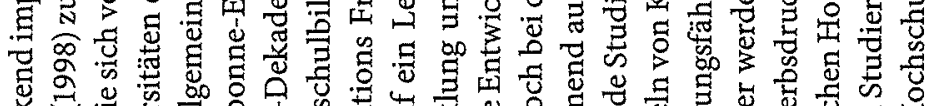

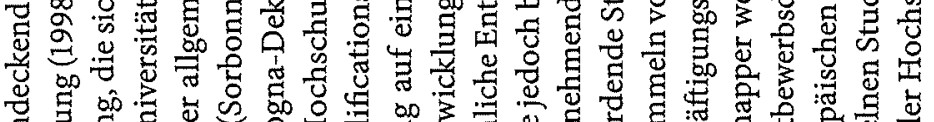

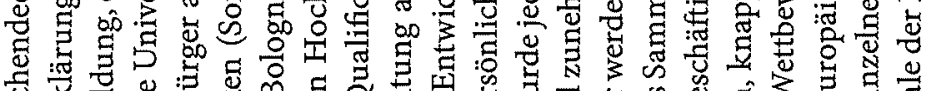

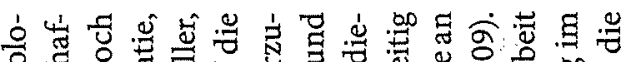

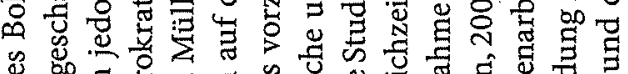

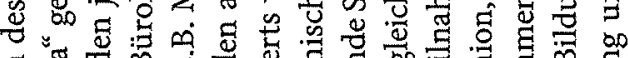

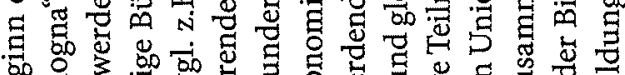

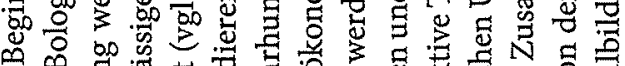

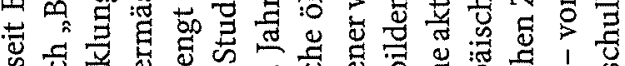
क

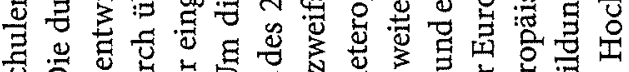

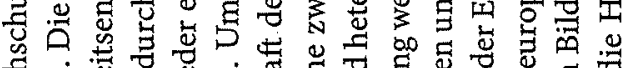

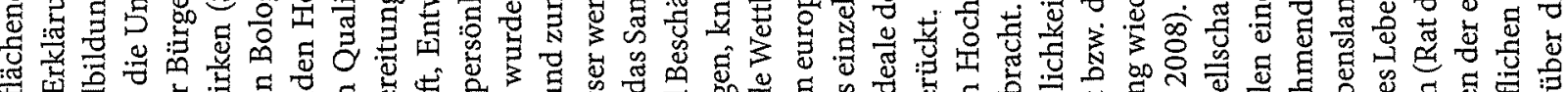

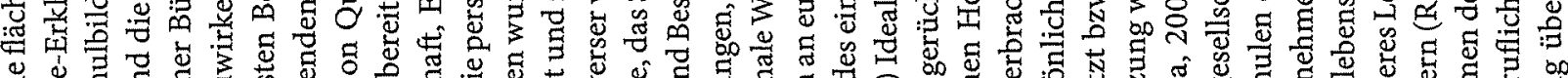

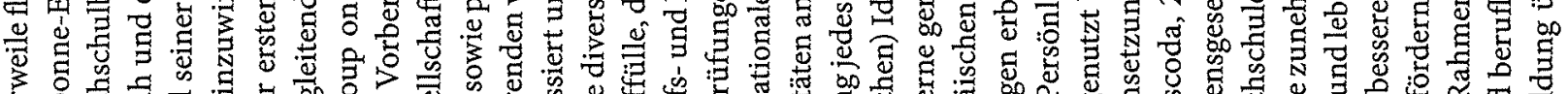

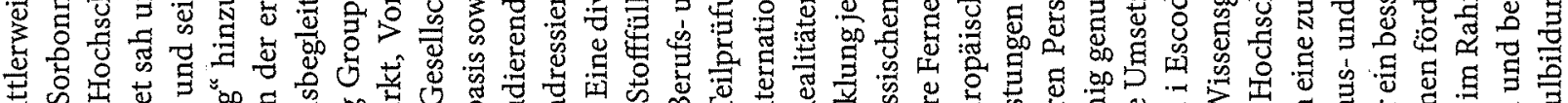

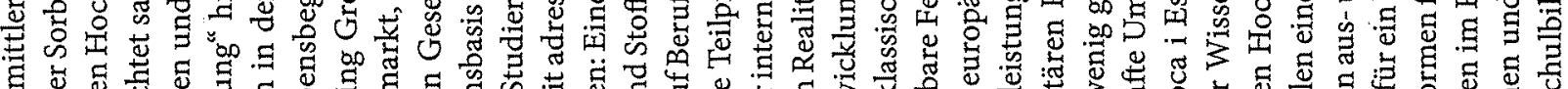

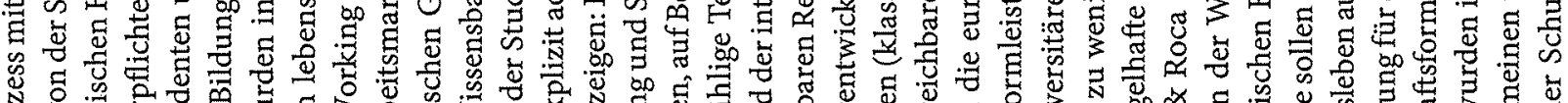
N

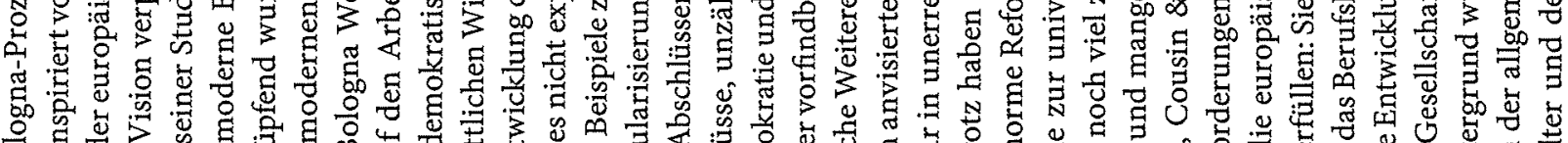

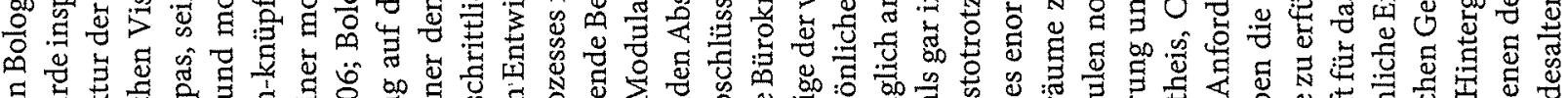

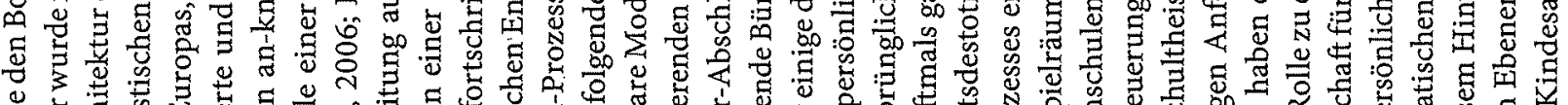

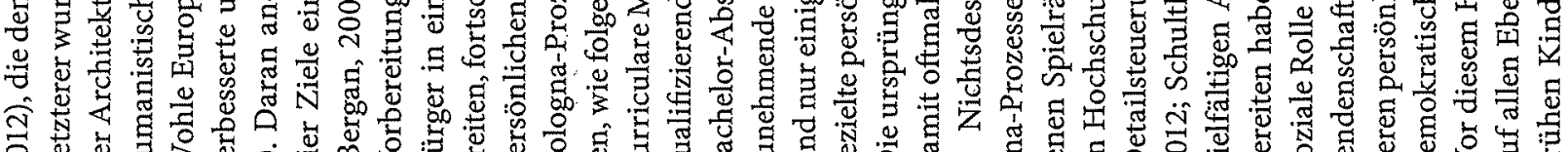

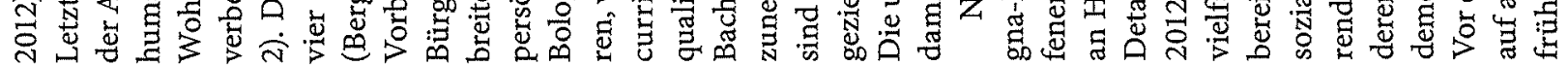

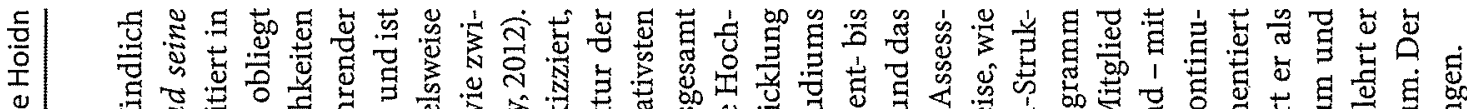

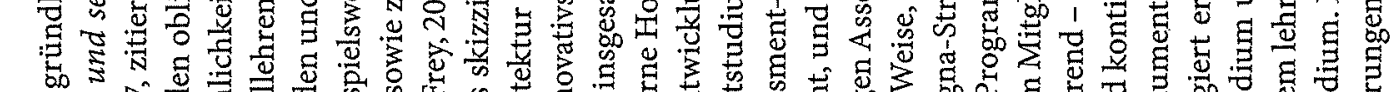

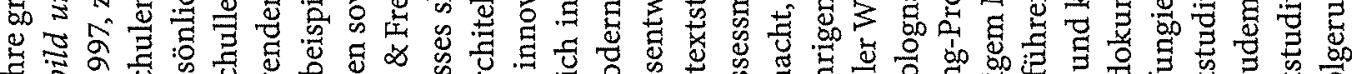

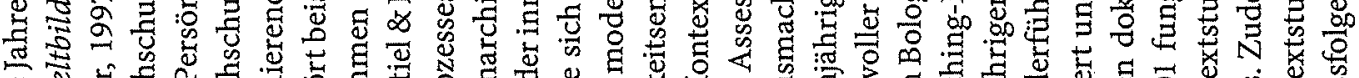

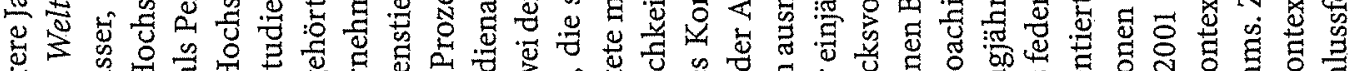

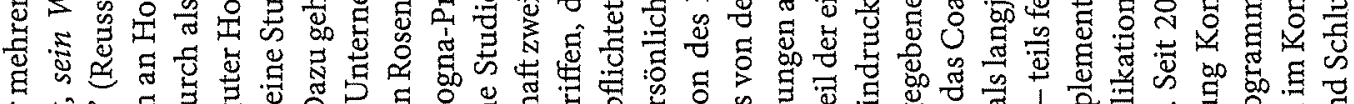

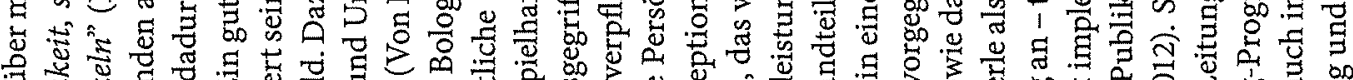

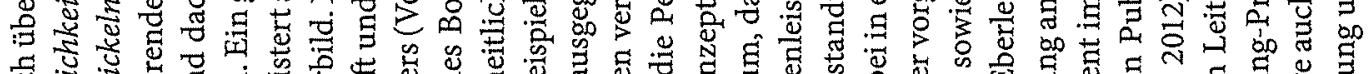

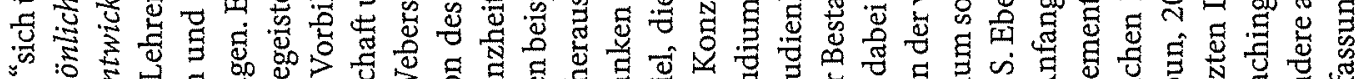

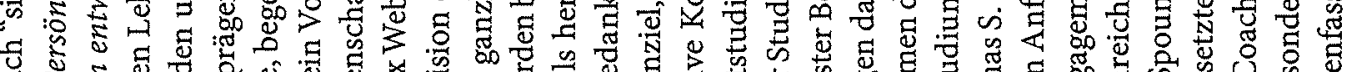

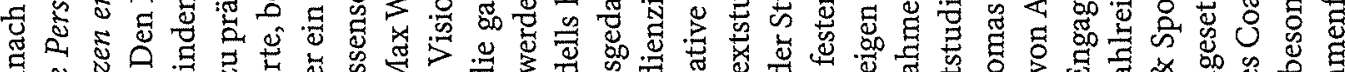

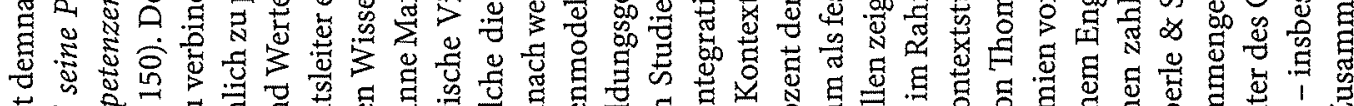

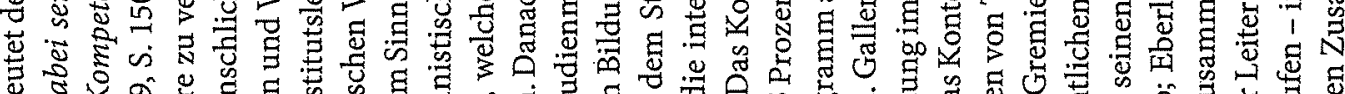

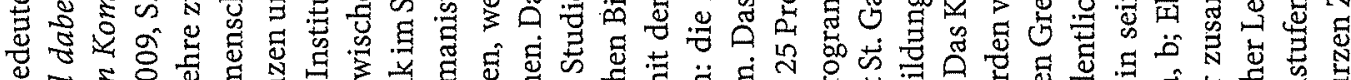

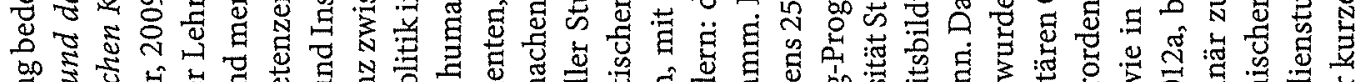

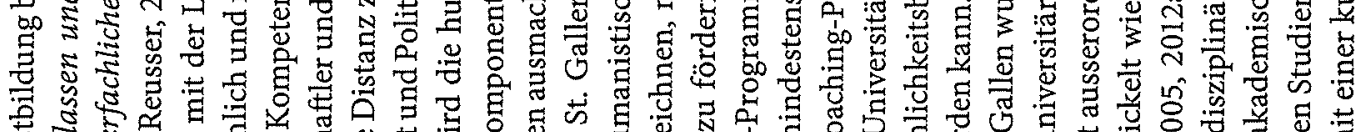

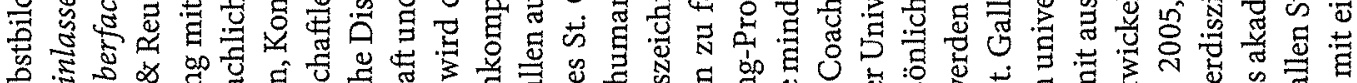

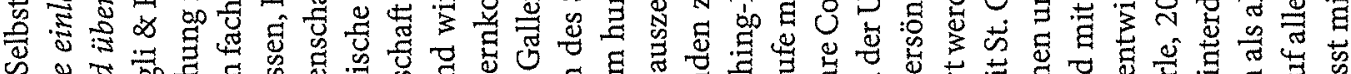

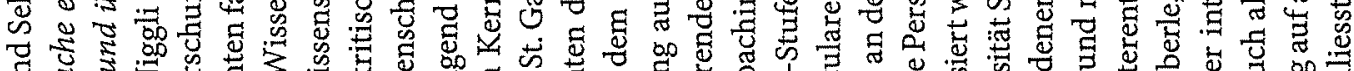

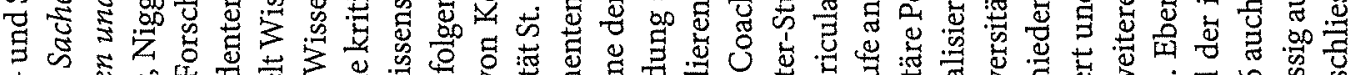

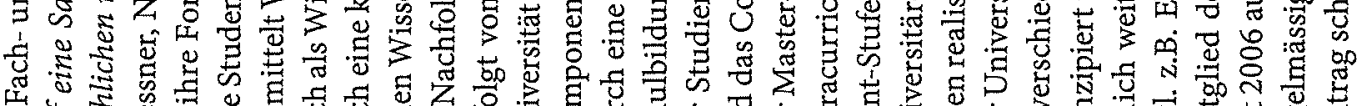

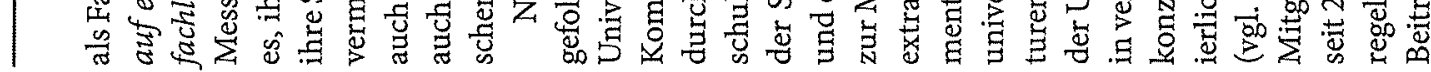




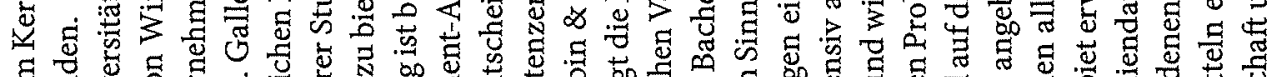

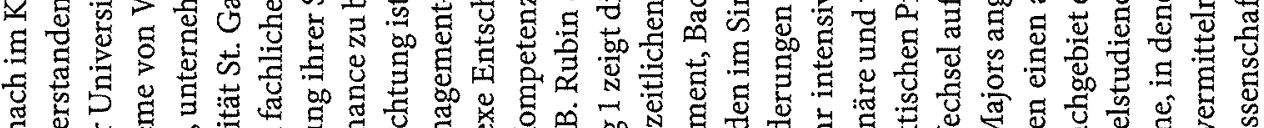
荡

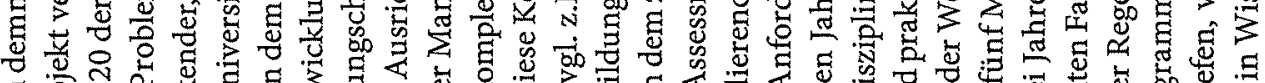

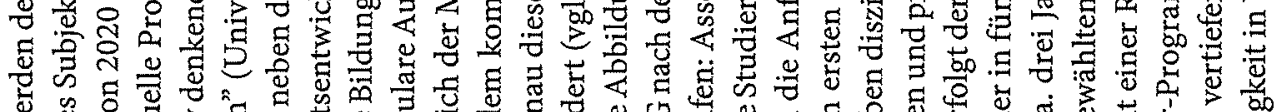

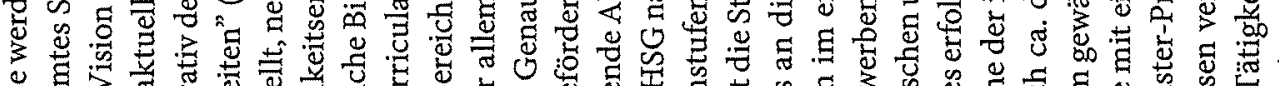

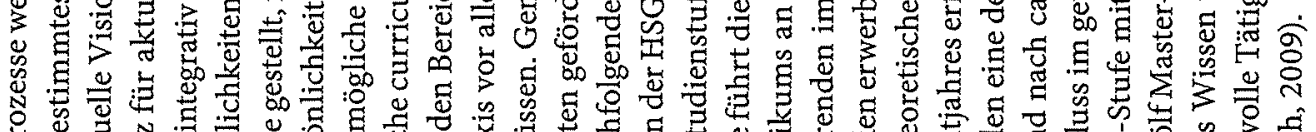

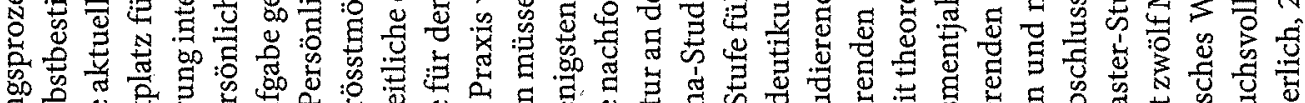

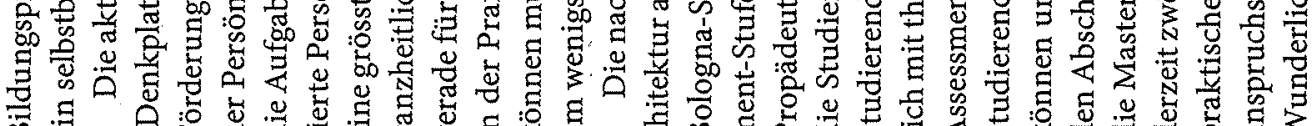

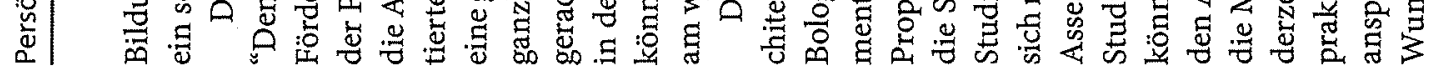

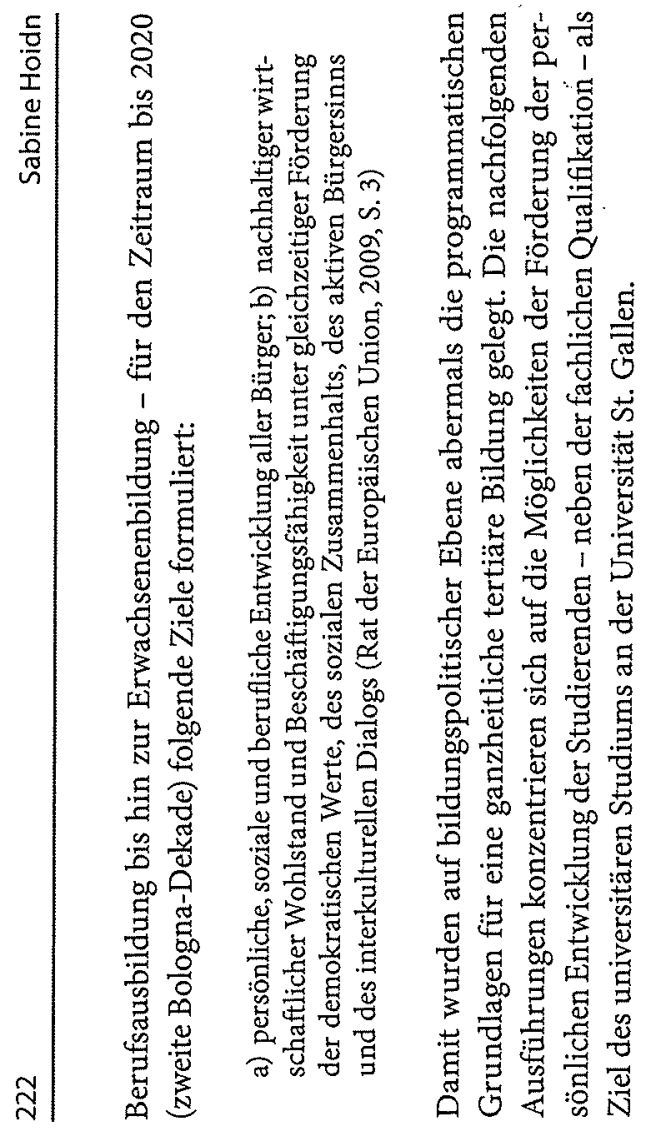

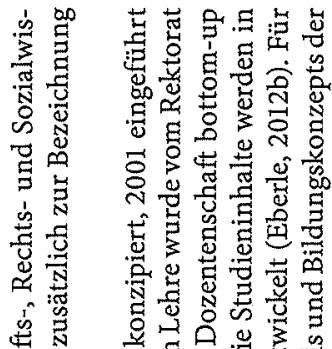

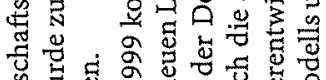

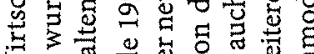
ऊु

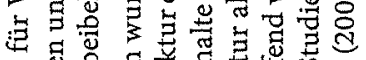
을 兘总

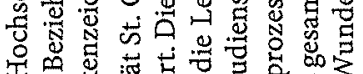
w

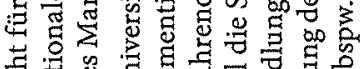

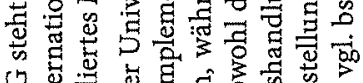

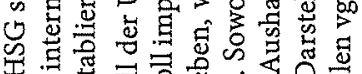
设

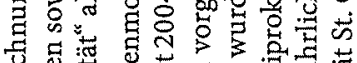

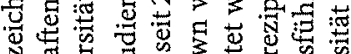

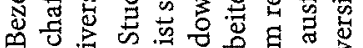

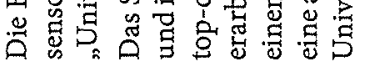



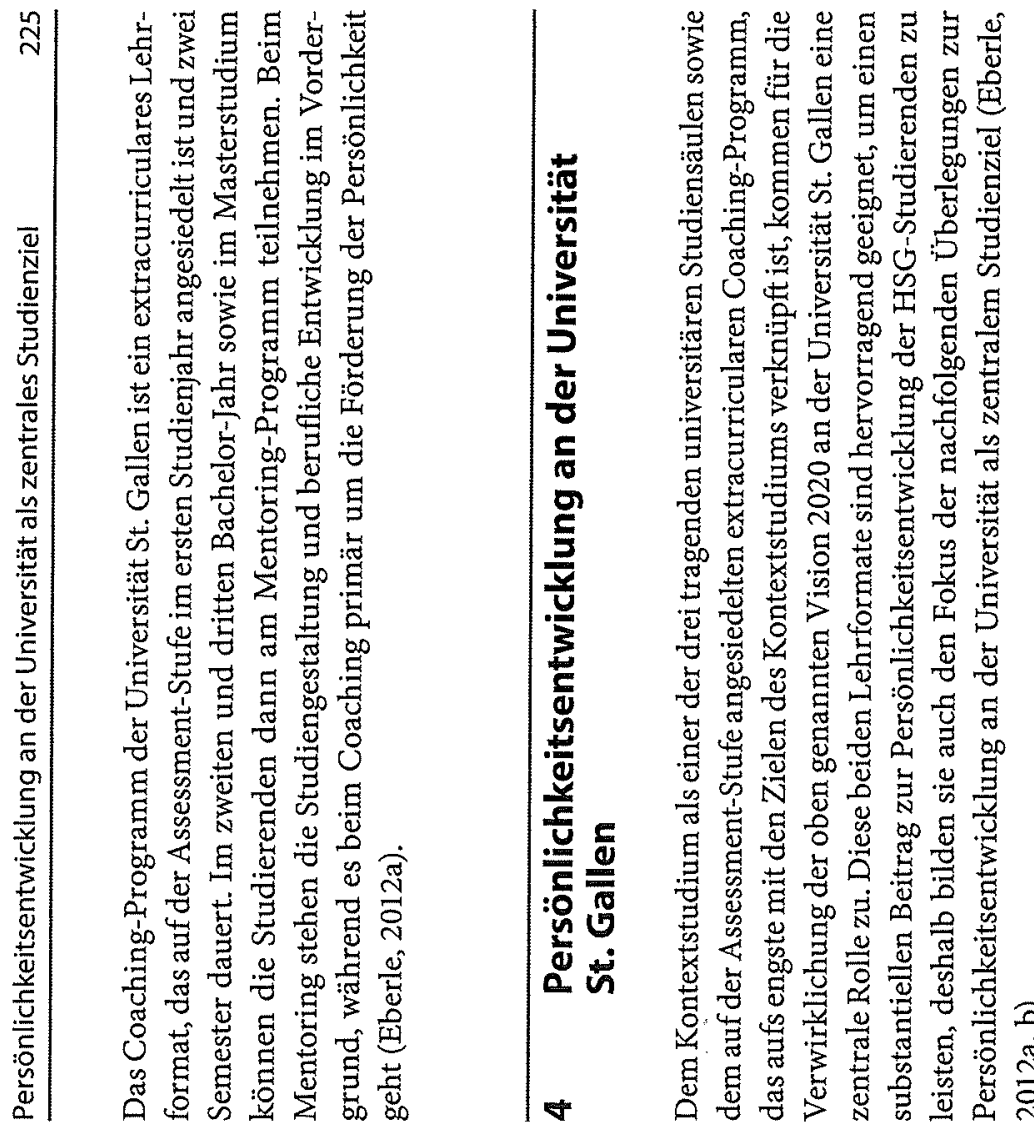

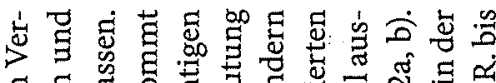
:

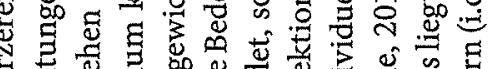

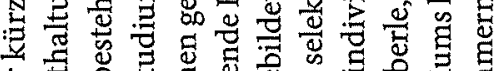

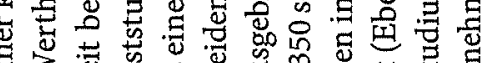
"

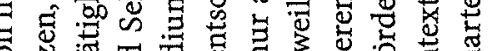

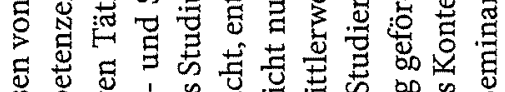

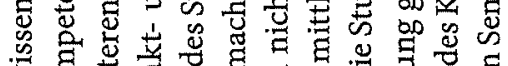

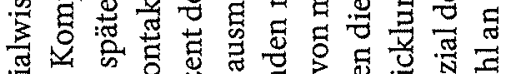

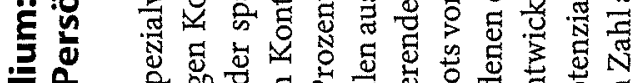

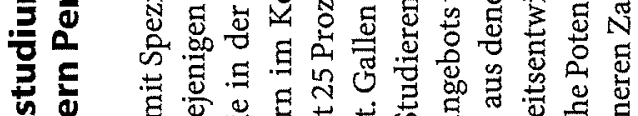

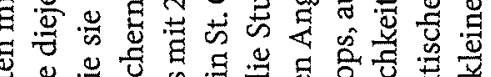

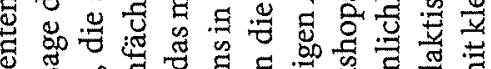

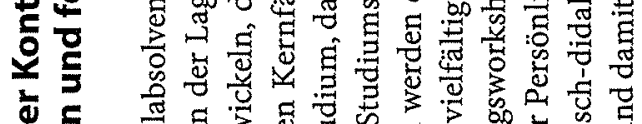

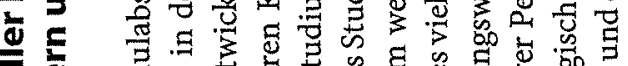

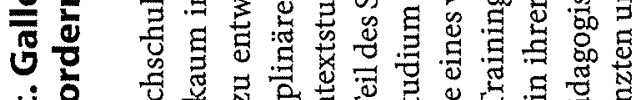

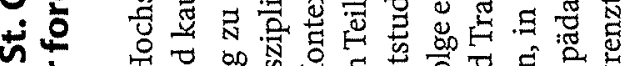

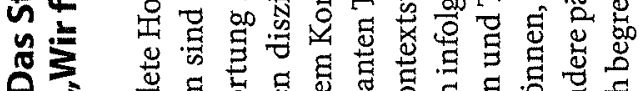

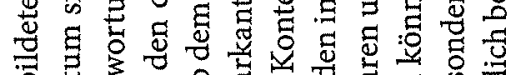

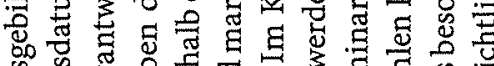

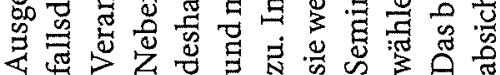

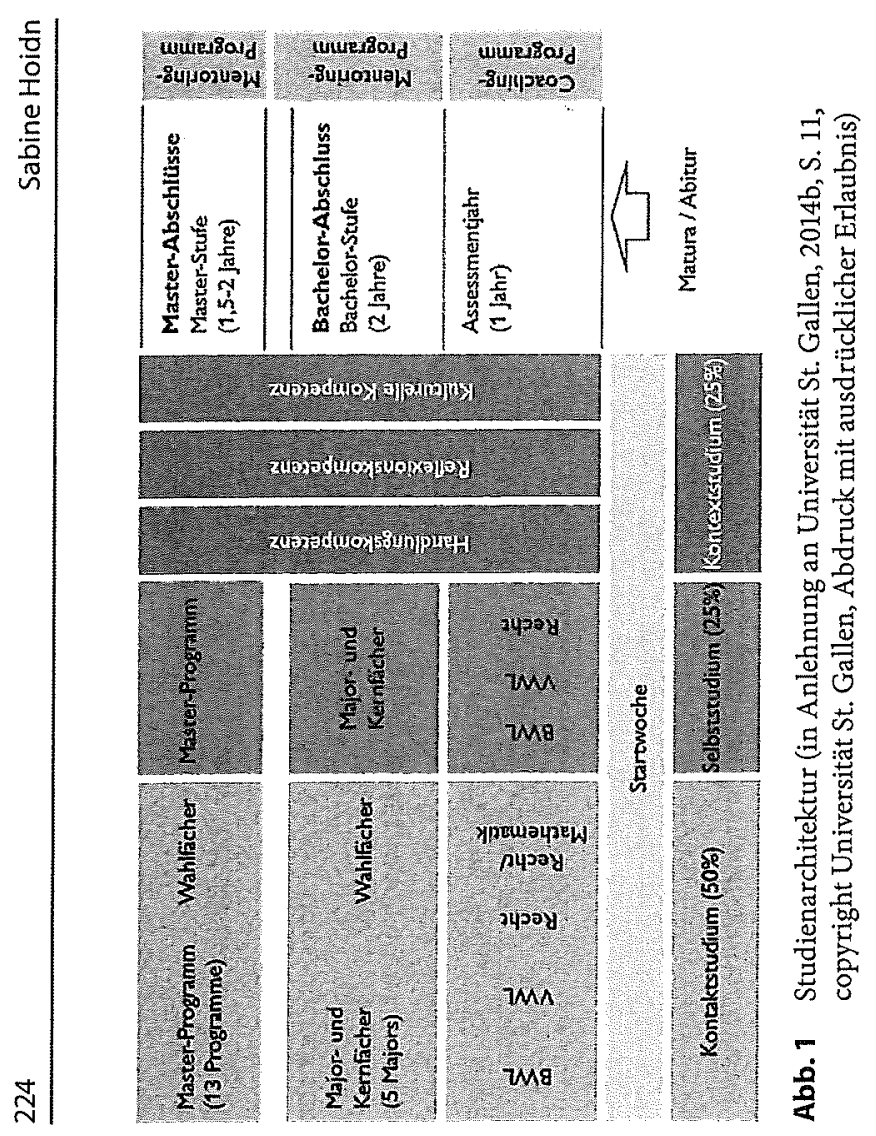

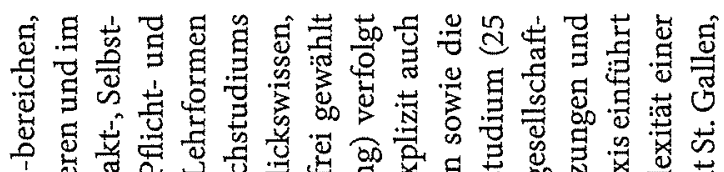

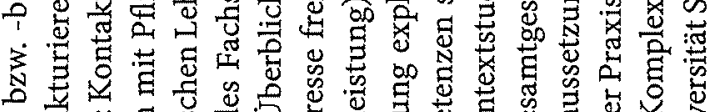

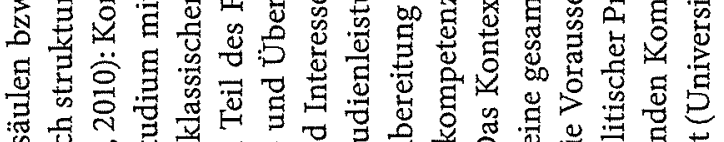

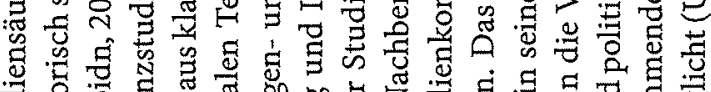

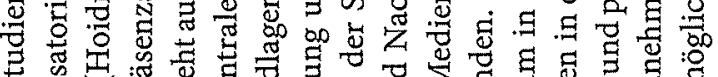

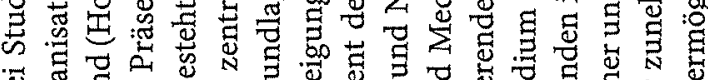

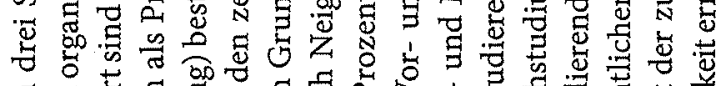

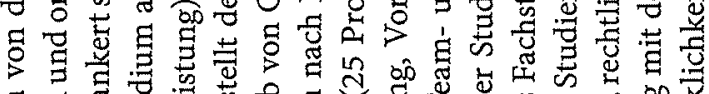

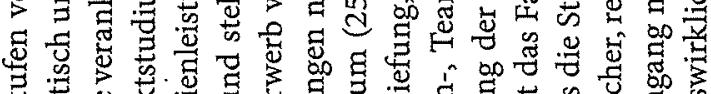

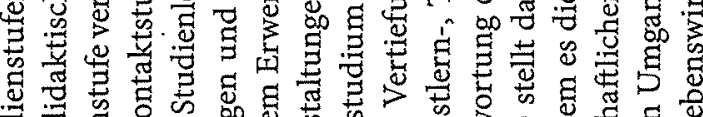

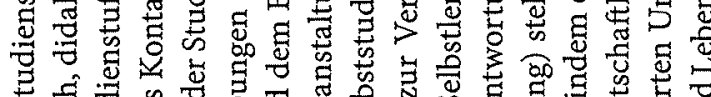

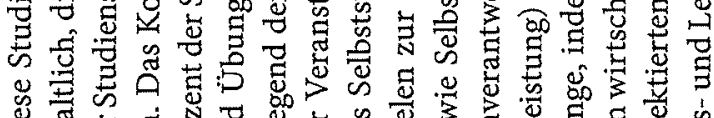

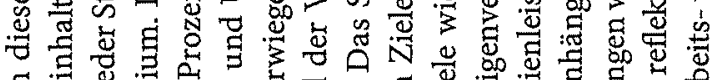

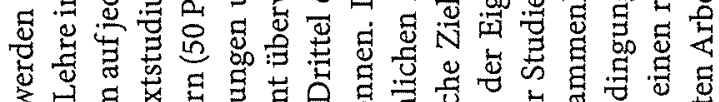

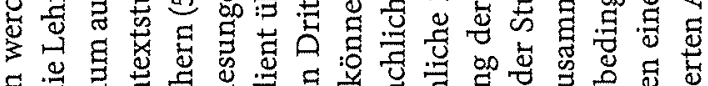

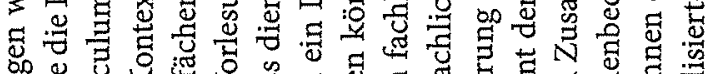

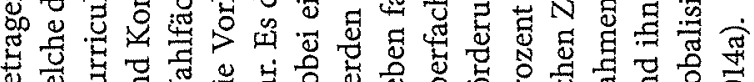

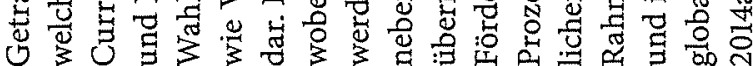




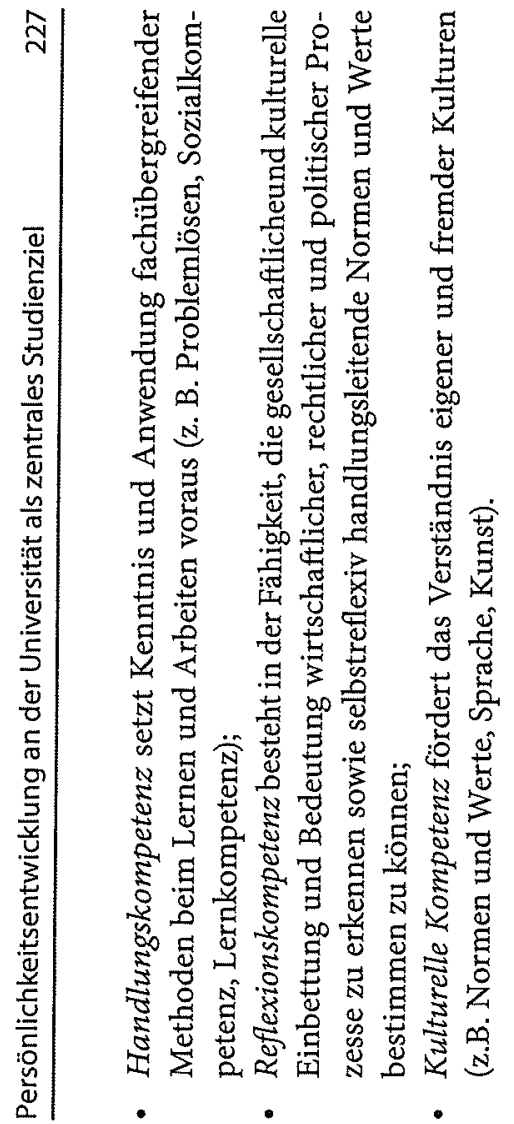

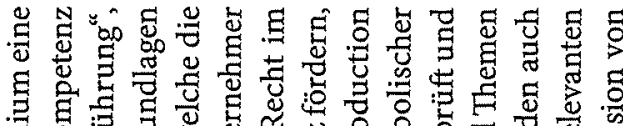

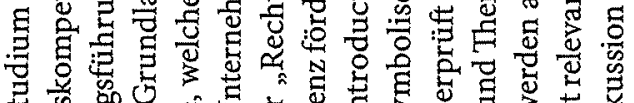

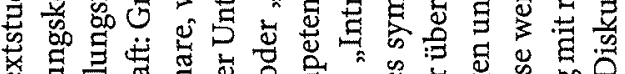

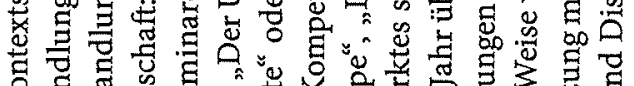

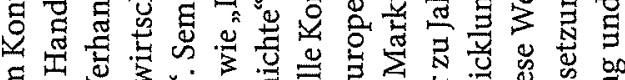

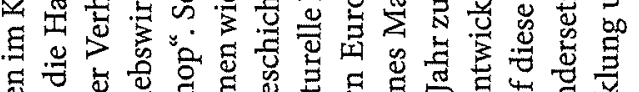

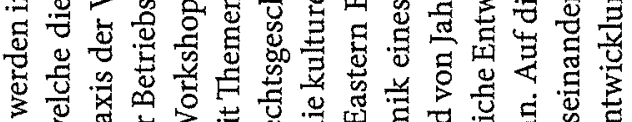

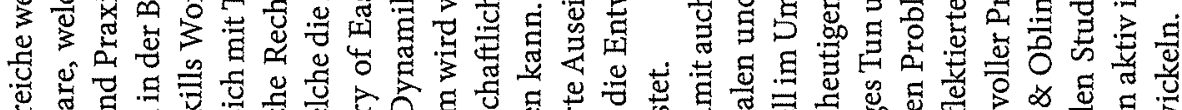

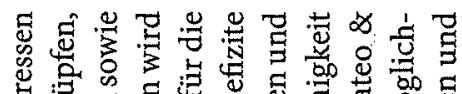

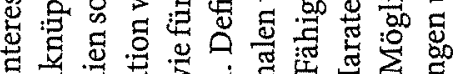

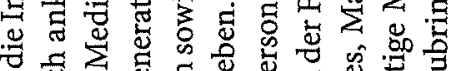

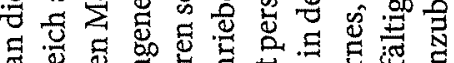

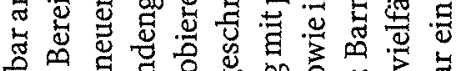

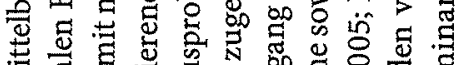

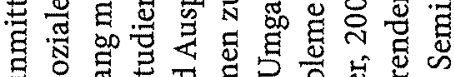

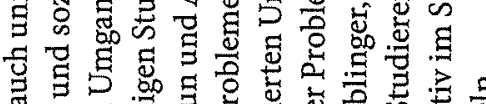

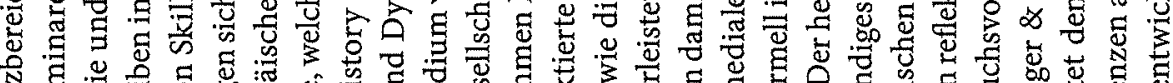

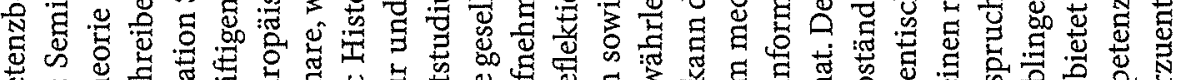

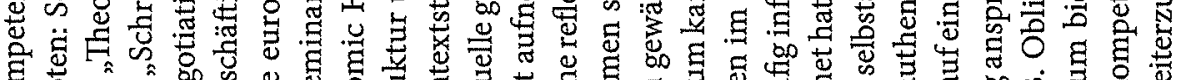

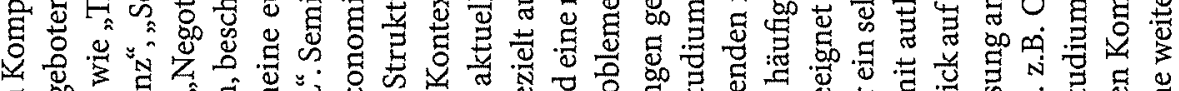

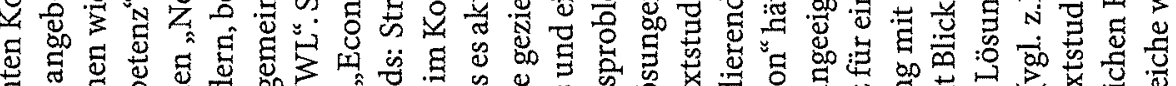

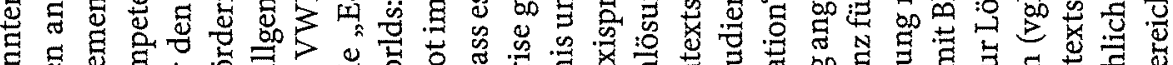

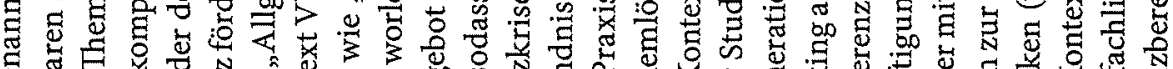

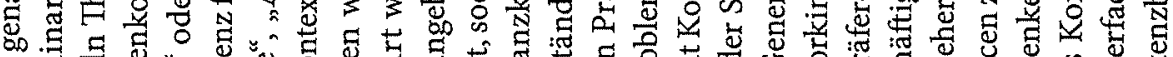
ब.

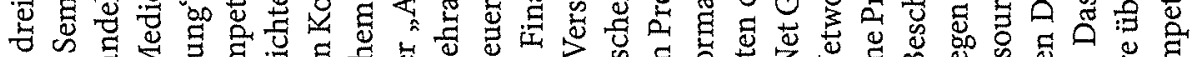

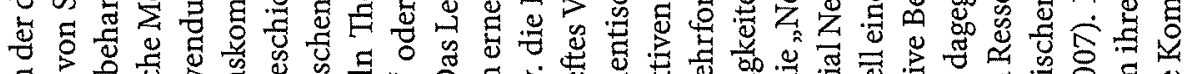

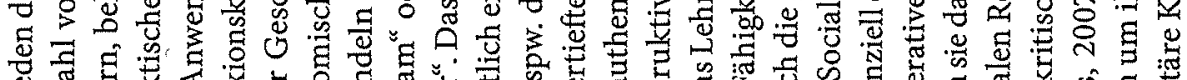

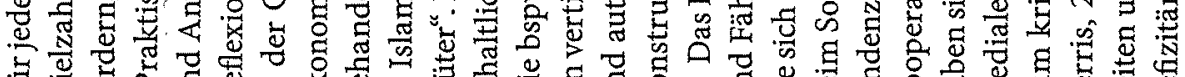

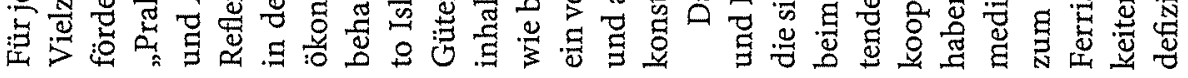

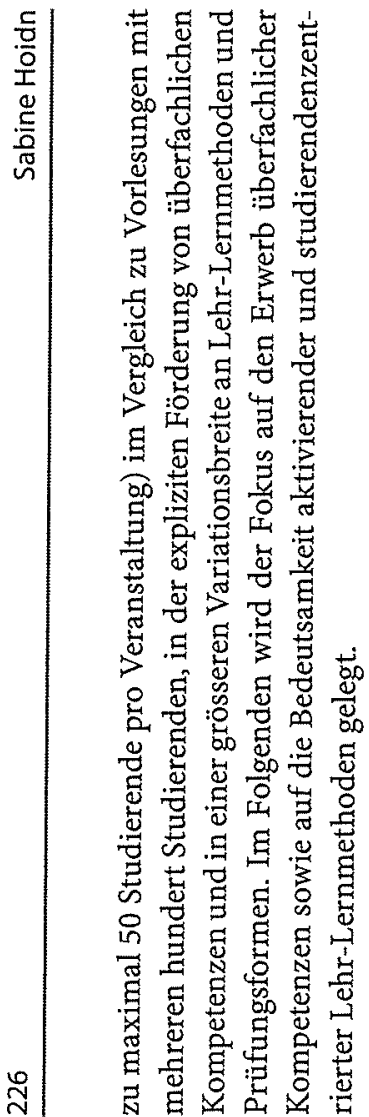

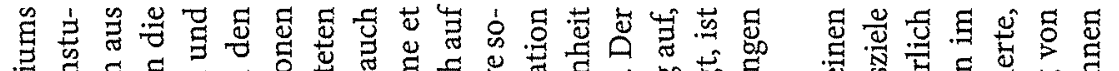

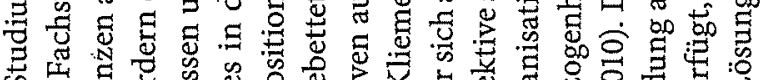
क

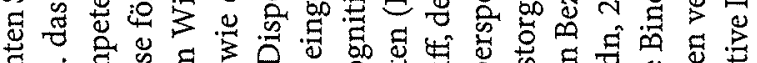

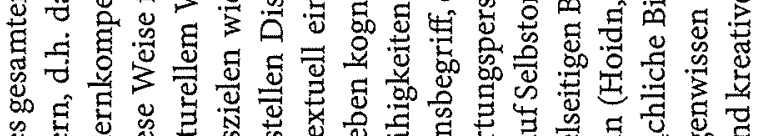

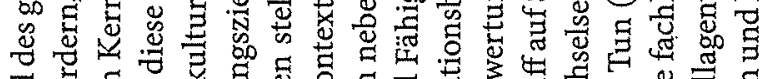

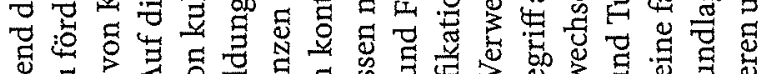

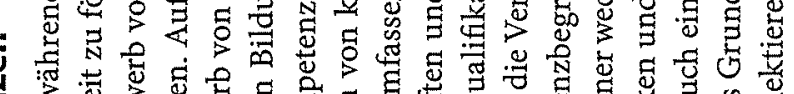

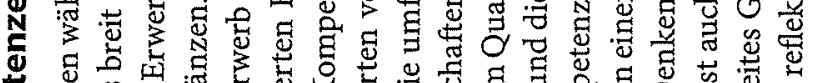

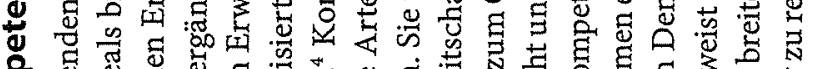

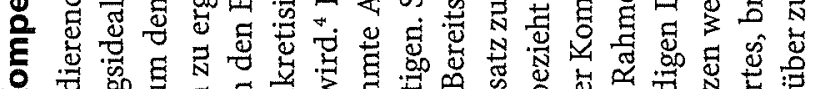

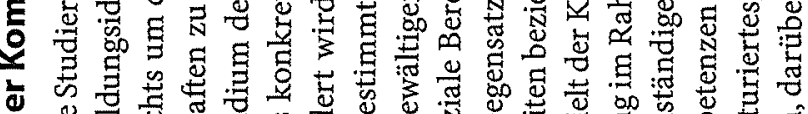

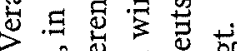

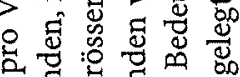
ชै

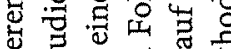
च

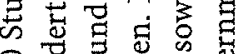
约 ह

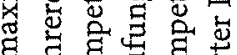

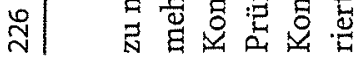

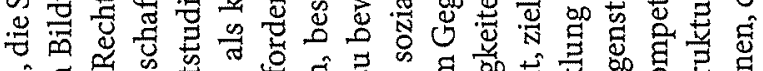

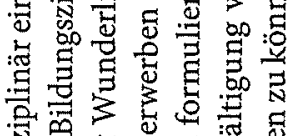

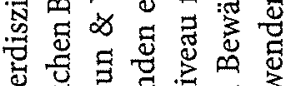

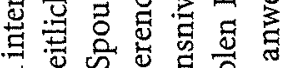
氜 की

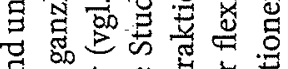

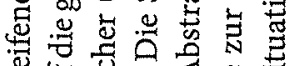

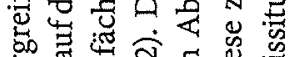

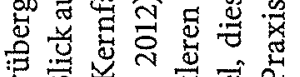

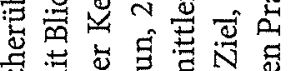

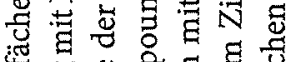

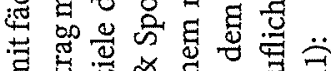

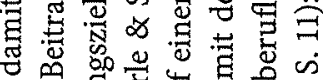

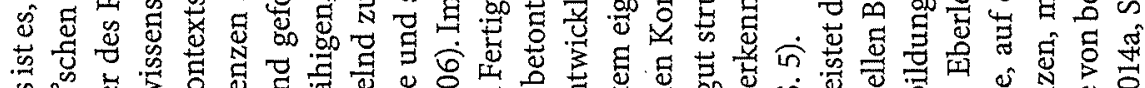

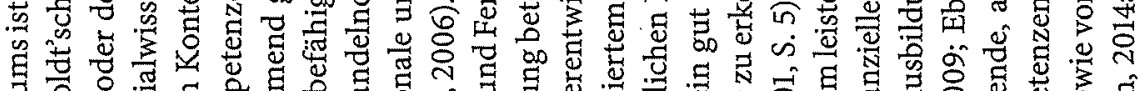

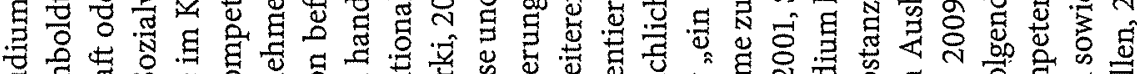

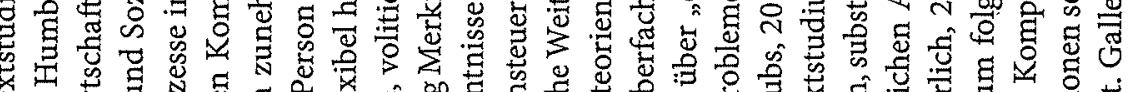

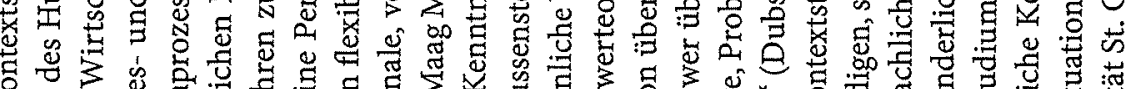

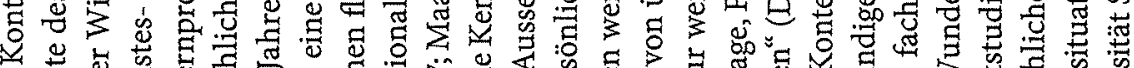

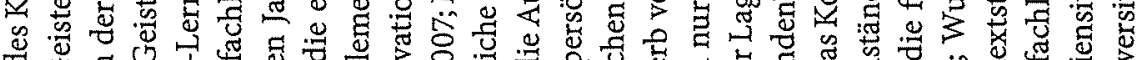

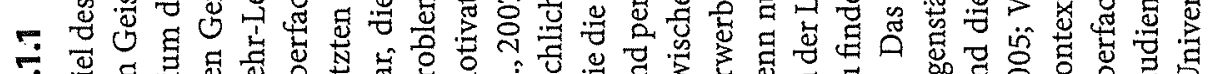
部

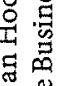

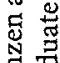

$\overleftrightarrow{\circ}$

范

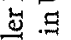

莺

콜

焉手

햄요

:형ำ 空文

क윰

总

눌

可崩

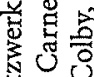

过艺

영

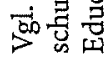




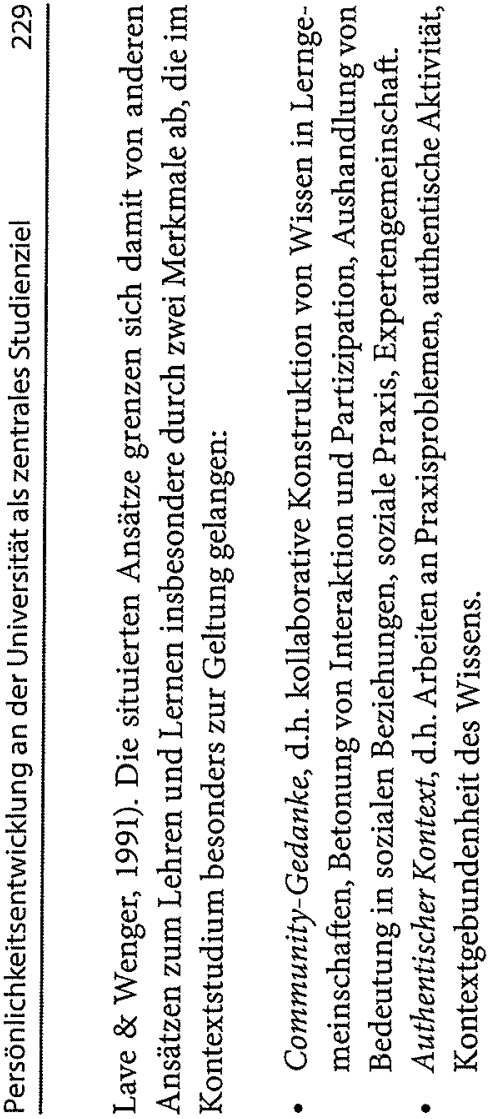

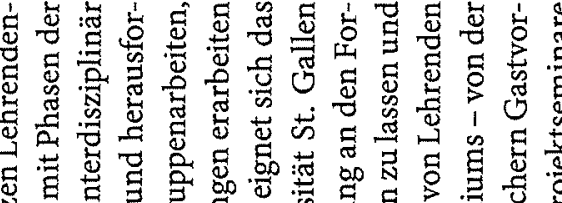

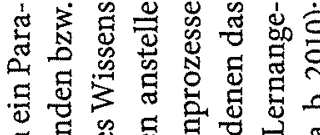

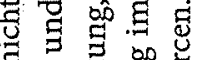

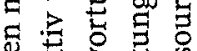

ह :

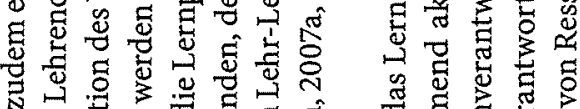

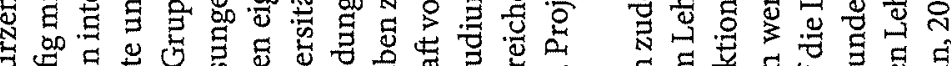

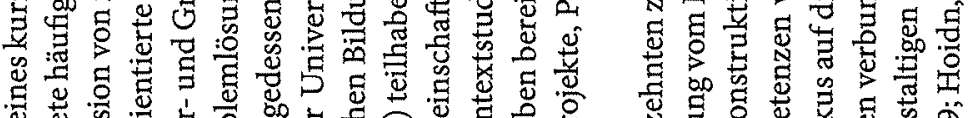

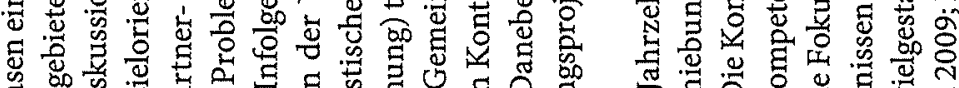

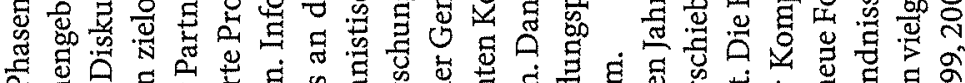

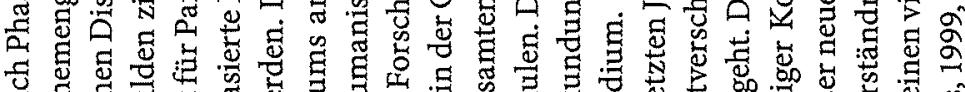

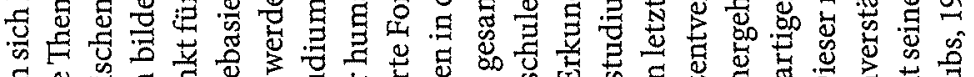

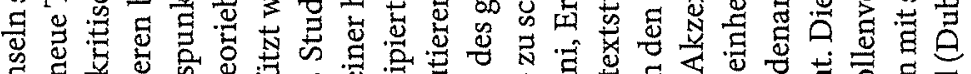

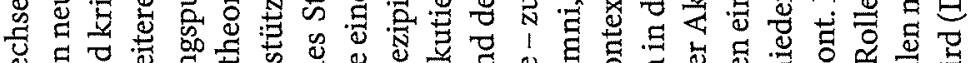

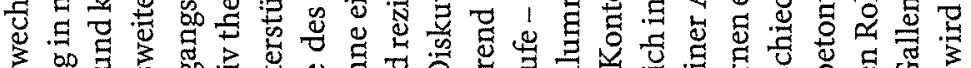

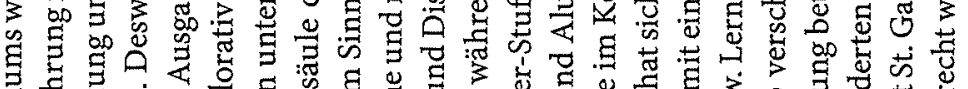

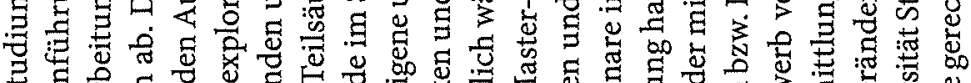

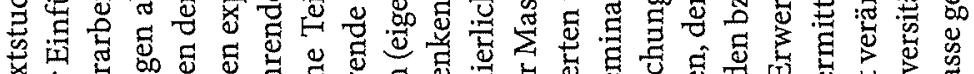

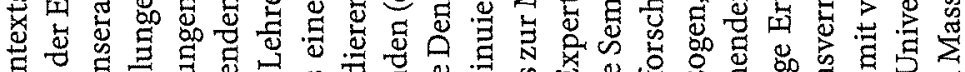

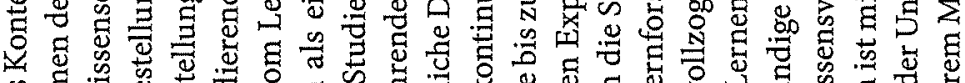

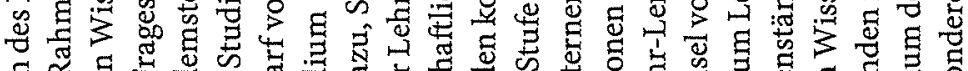

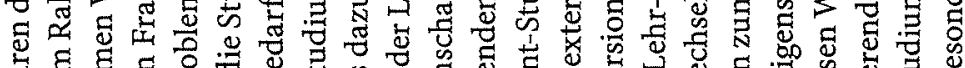

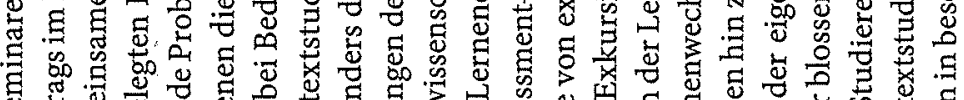

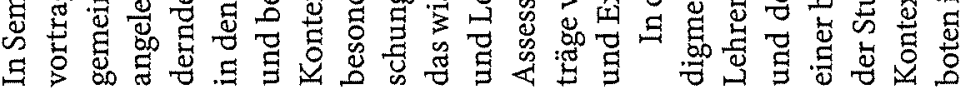

ชै

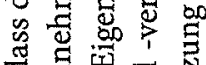

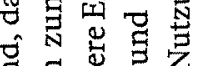

过 要焉焉 क

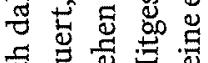
矛焉空 ¿. 要要

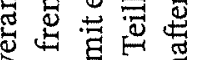

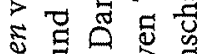
ฐ

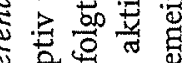
过密

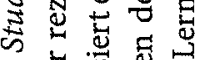

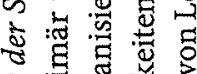
을 釒 吕焉遥

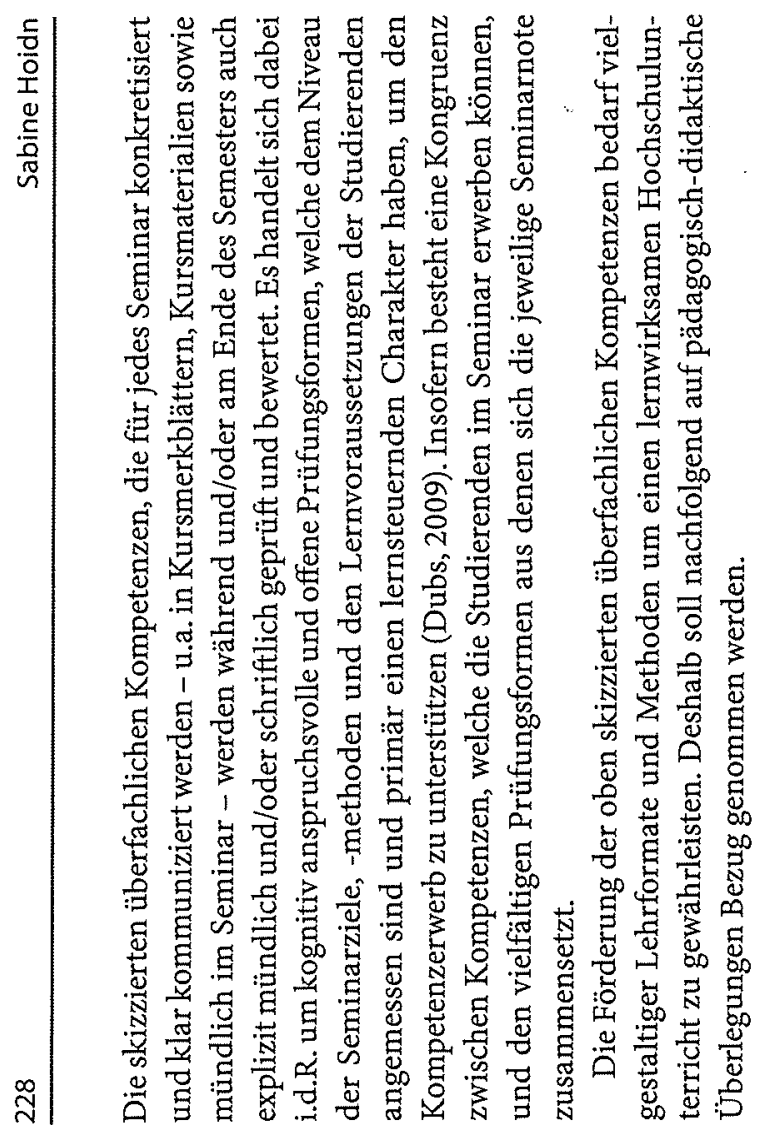

すี

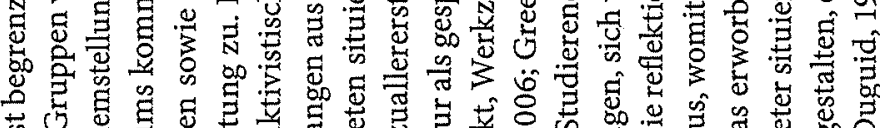

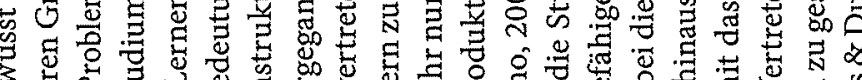

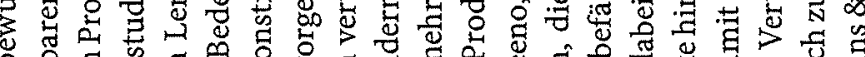

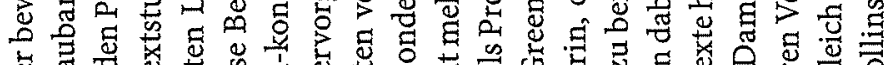

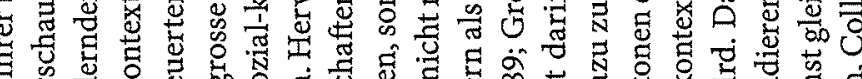

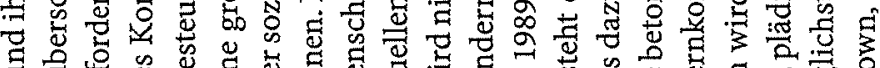

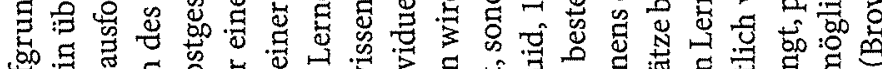

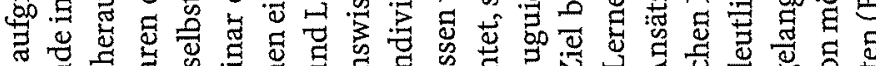

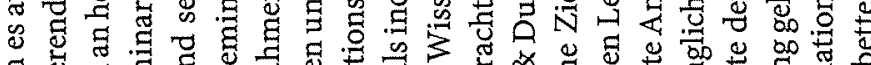

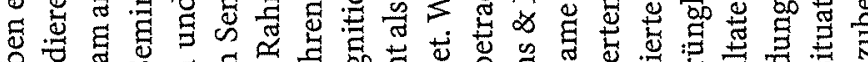

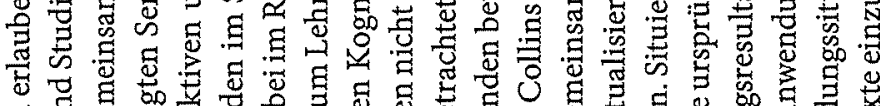

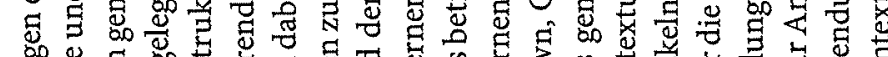

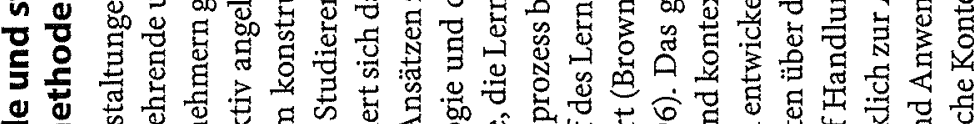

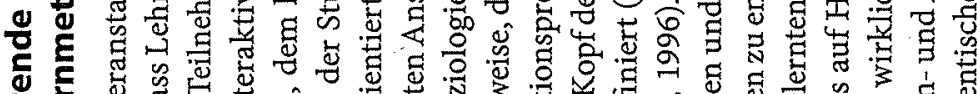

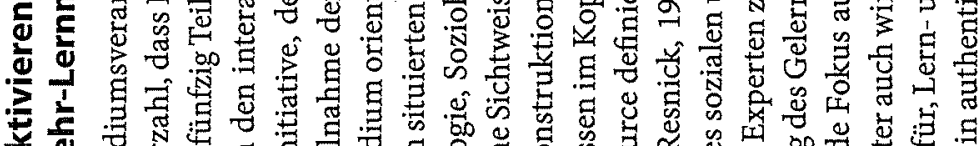

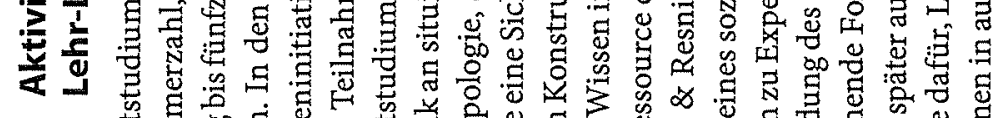

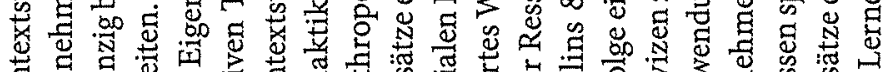

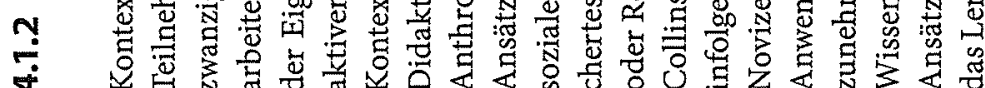




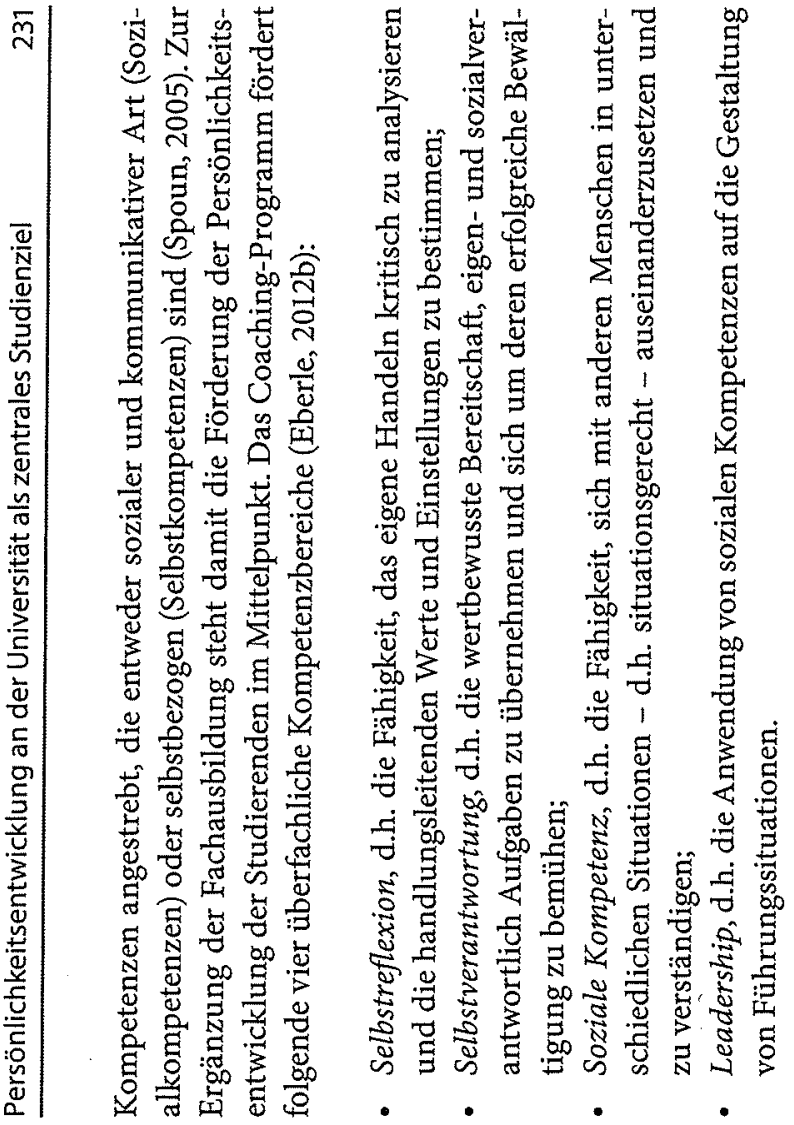

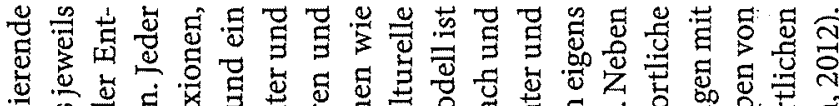

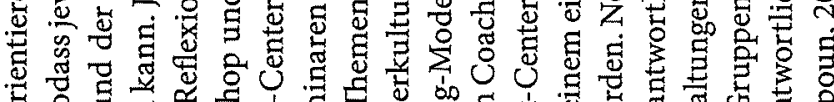

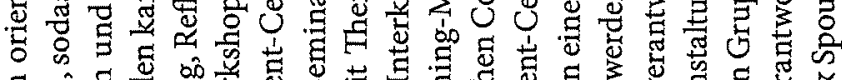

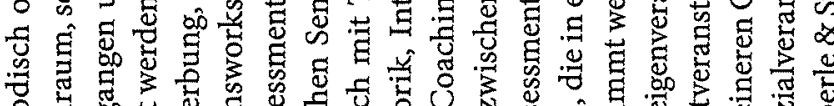

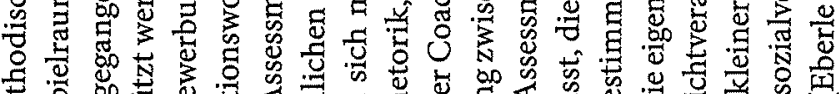

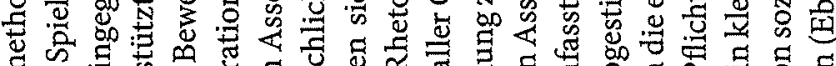

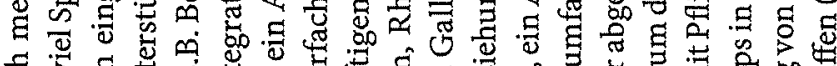

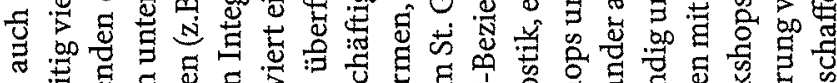

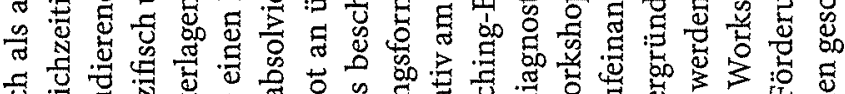

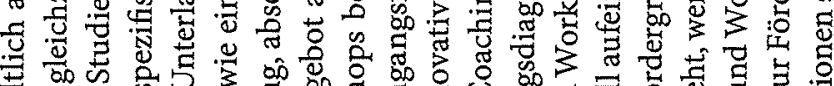

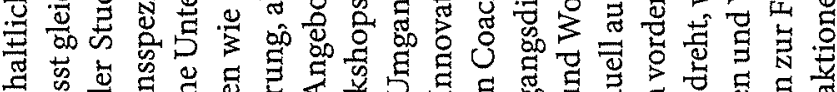

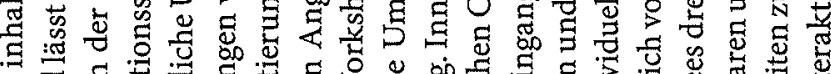

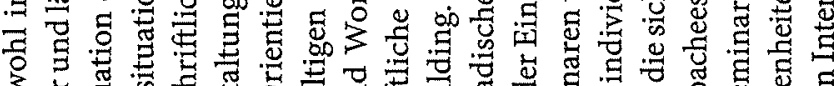

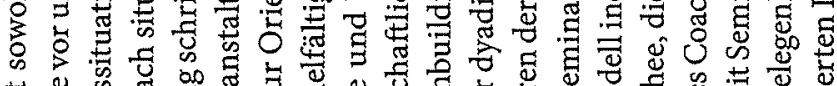

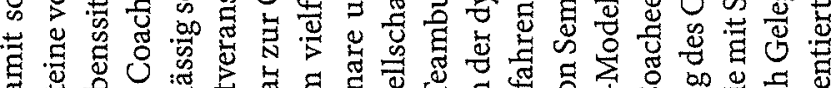

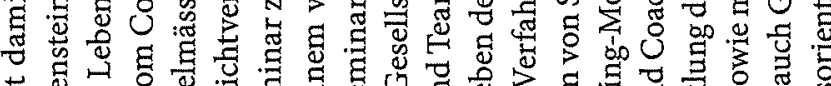

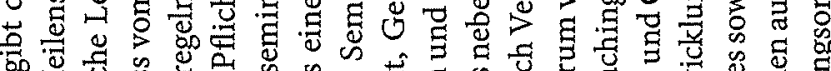

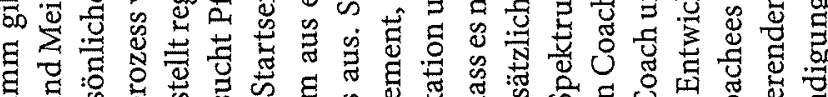

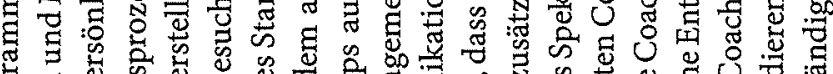

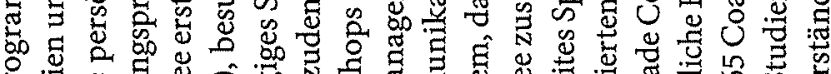

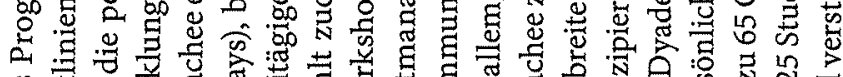

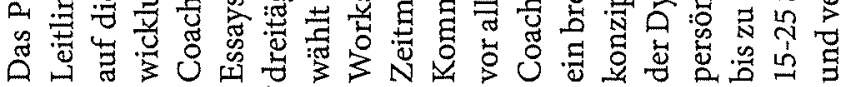

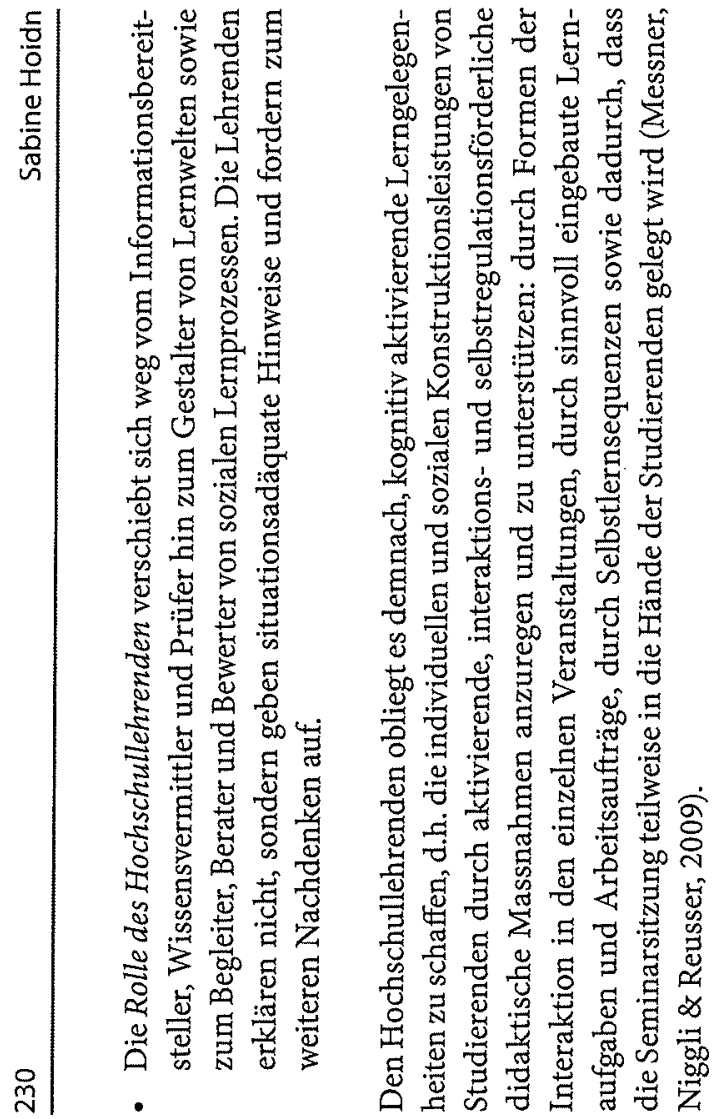

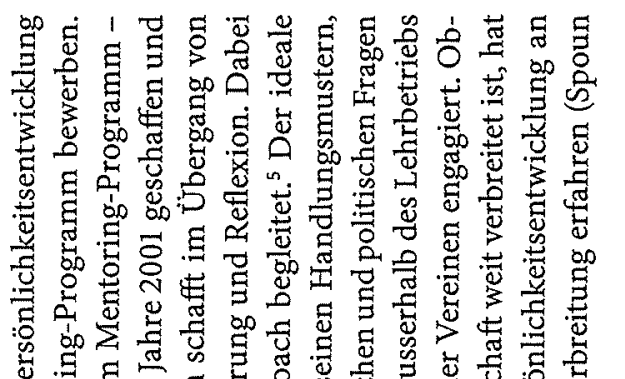

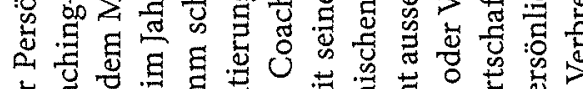

ह

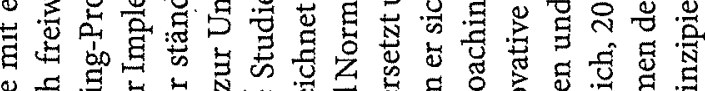

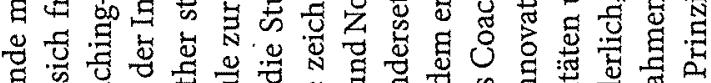
क $\rightarrow$ U 3 出

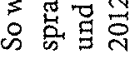




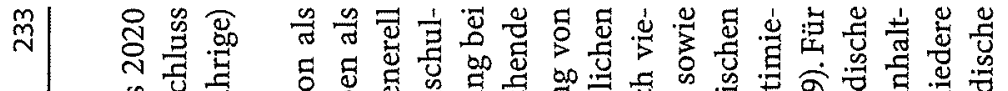

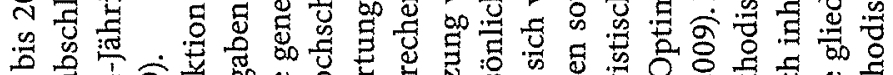

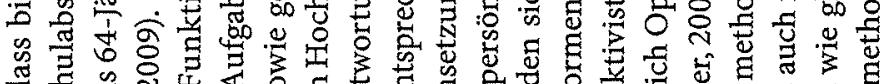

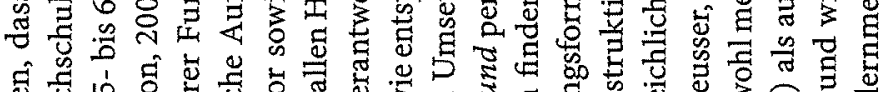

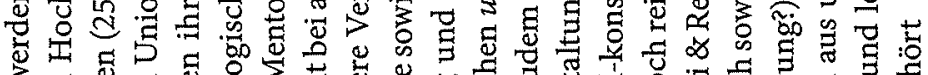

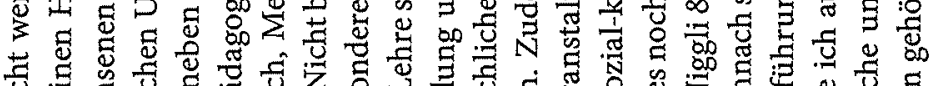

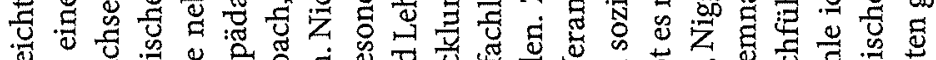

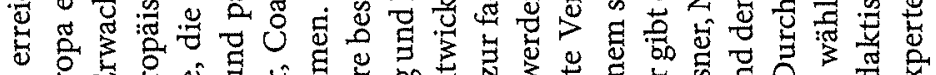

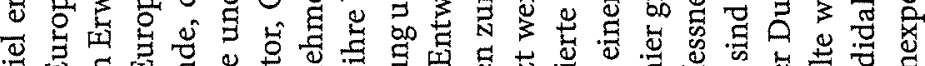

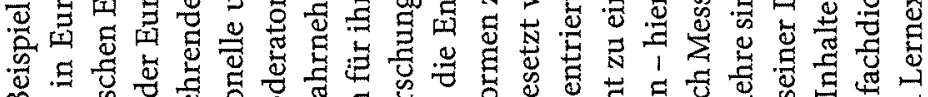
œ.

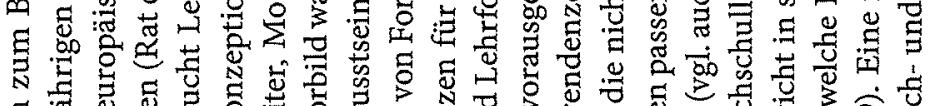

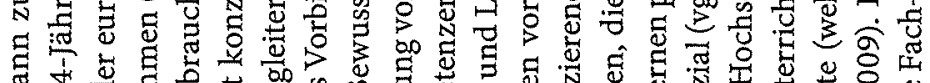

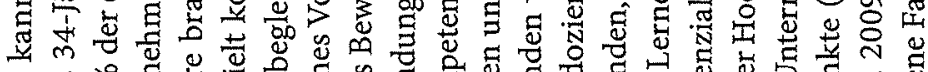

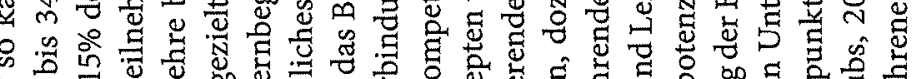

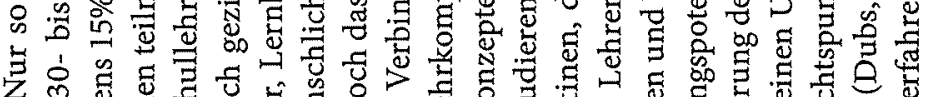

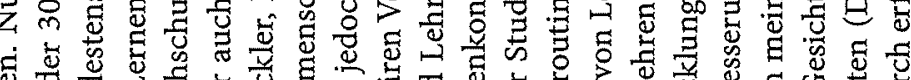

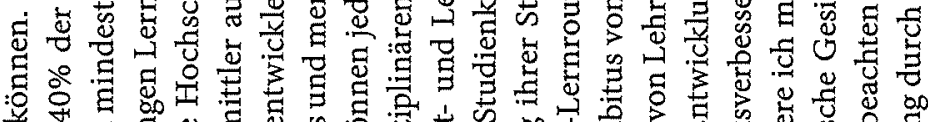

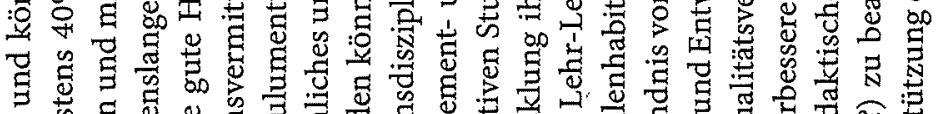

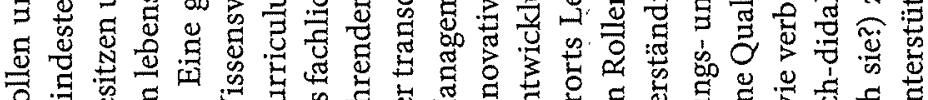

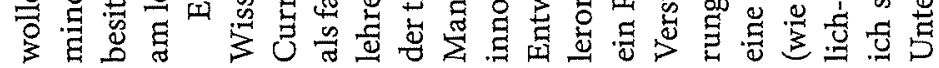

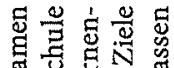

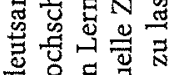
导证焉总

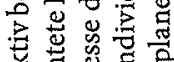

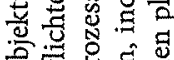
苟苛总芯 원

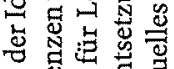

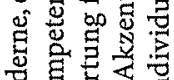

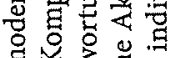

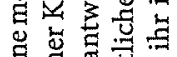

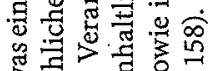
놀 든

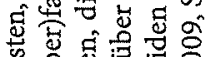
옹

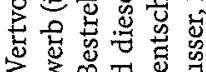

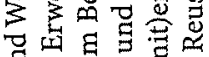
$\exists\left[\begin{array}{c}\Xi \\ g\end{array}\right.$

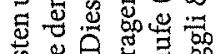

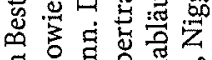

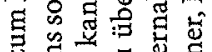

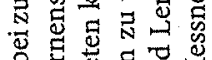

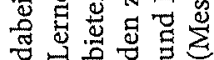

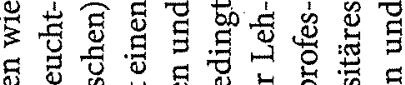

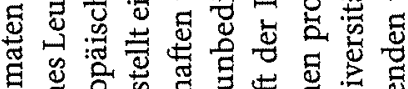

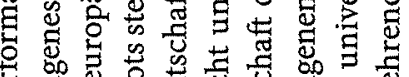

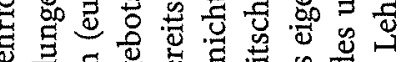

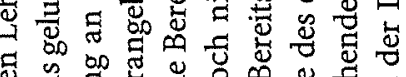

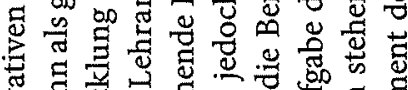

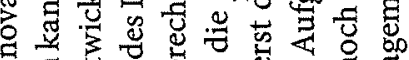
具昌

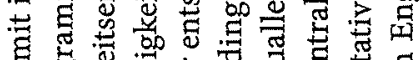

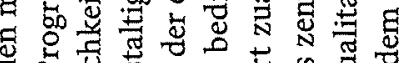
势

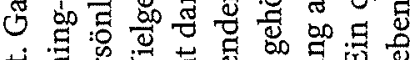

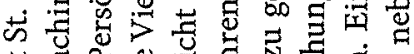

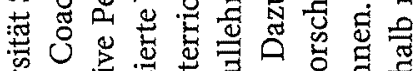
路

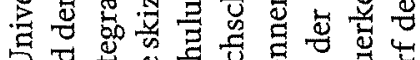

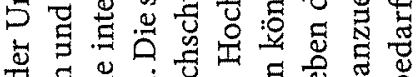

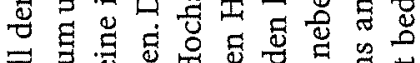
牙皮

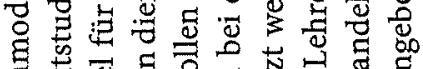

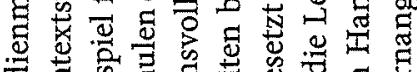

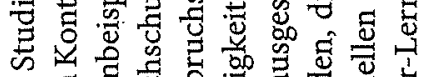

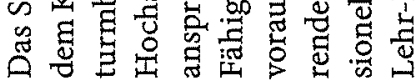

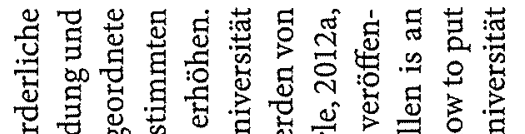

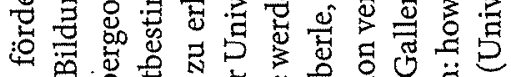

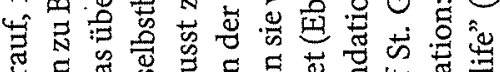

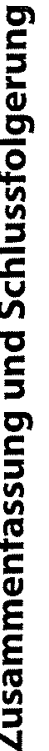

$\tilde{N}$

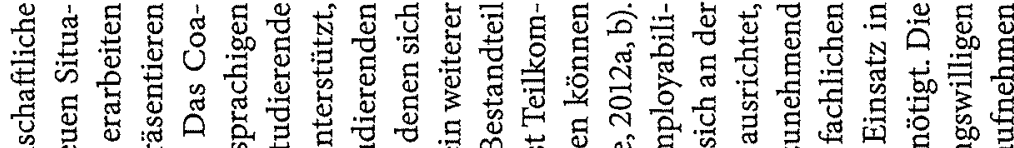

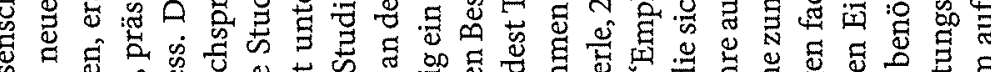

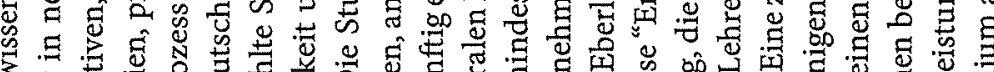

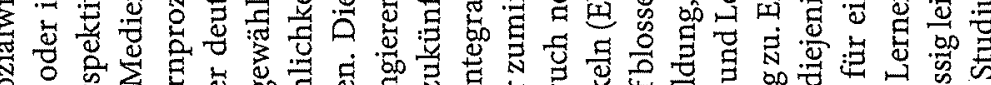

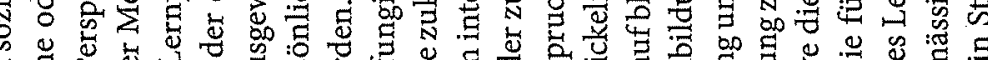

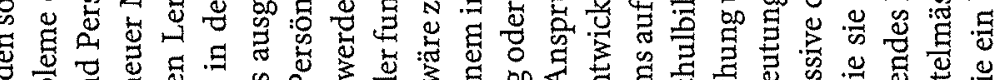

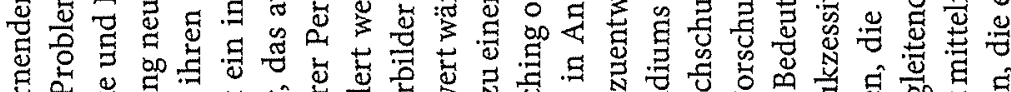
县

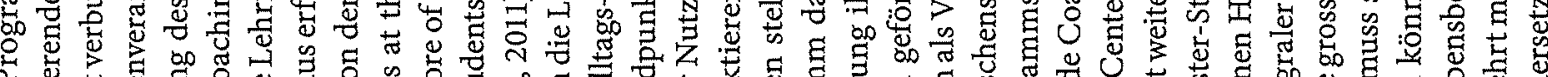

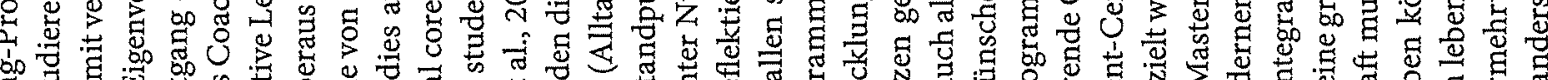

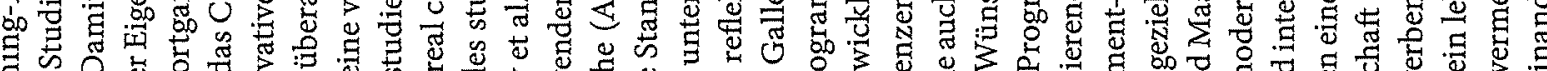

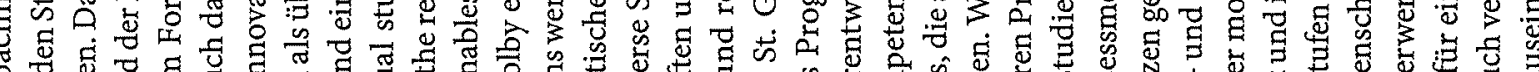

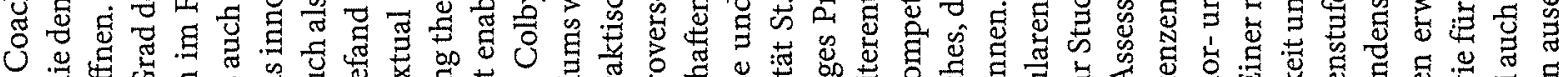

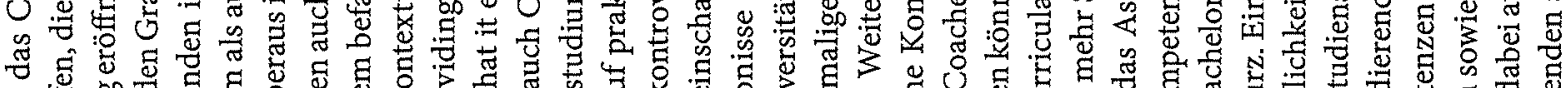

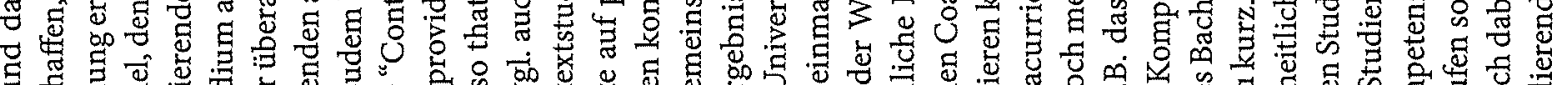

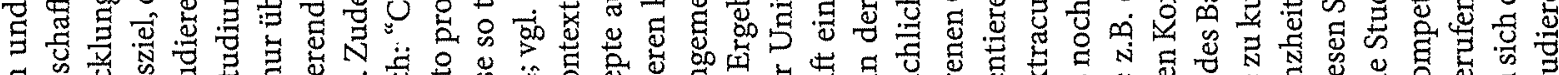

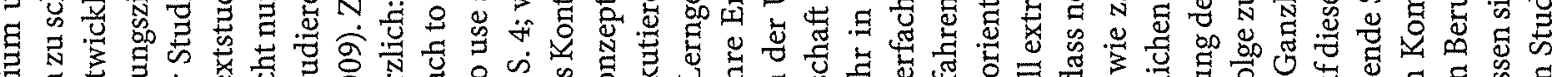

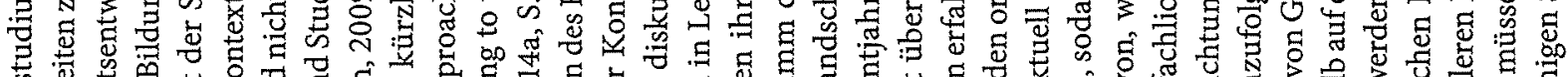

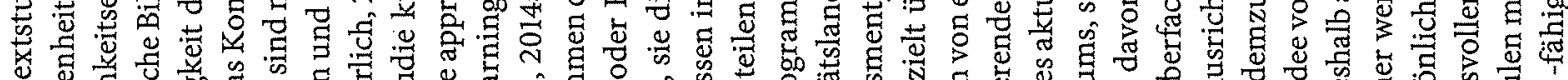

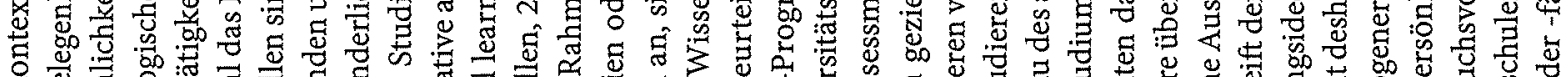

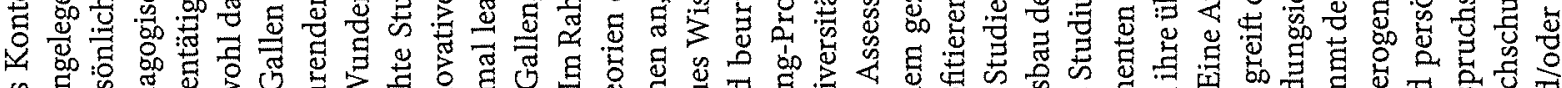

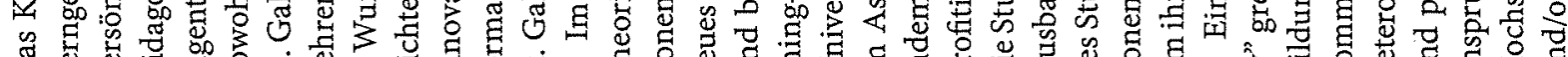




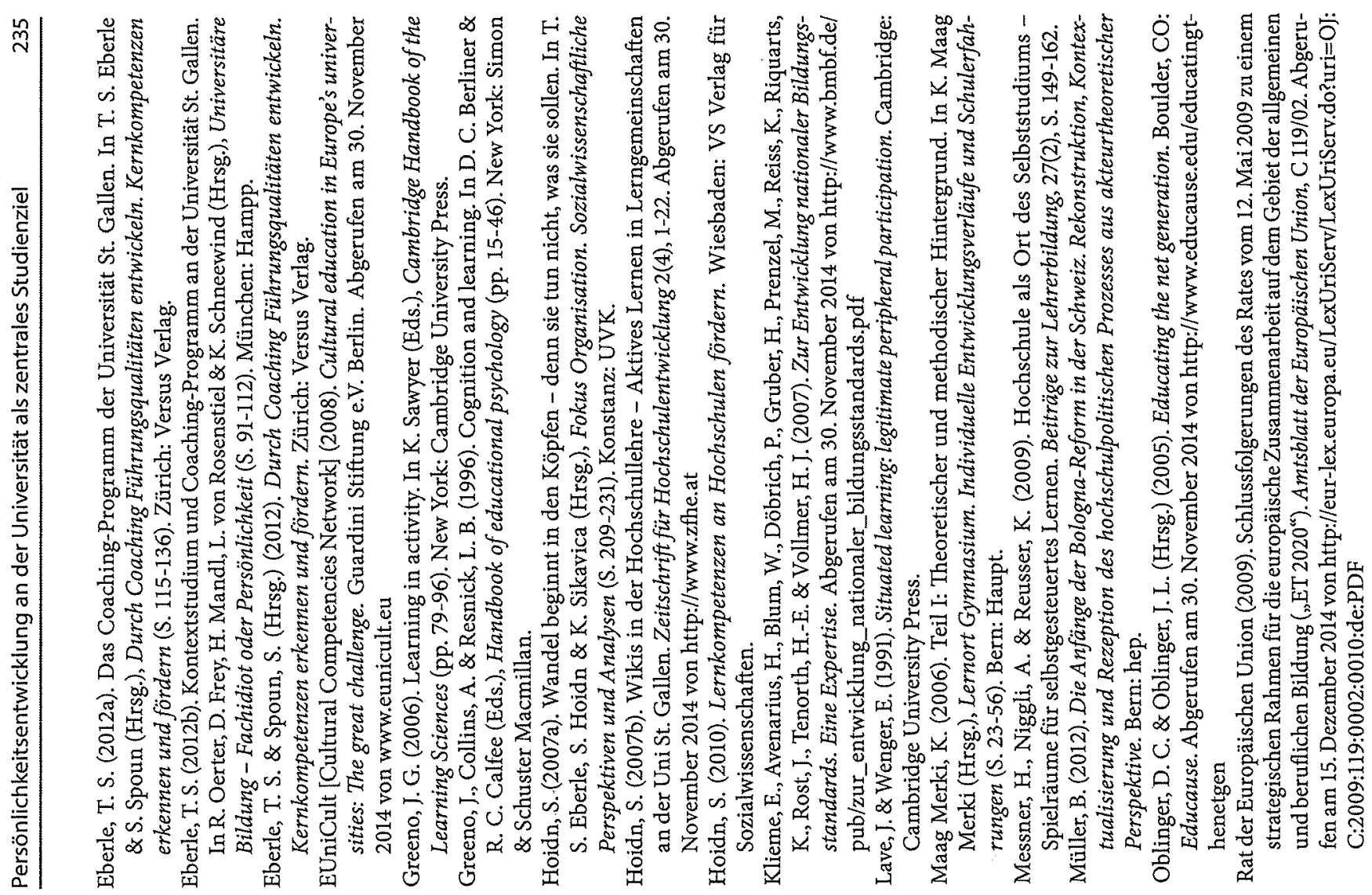
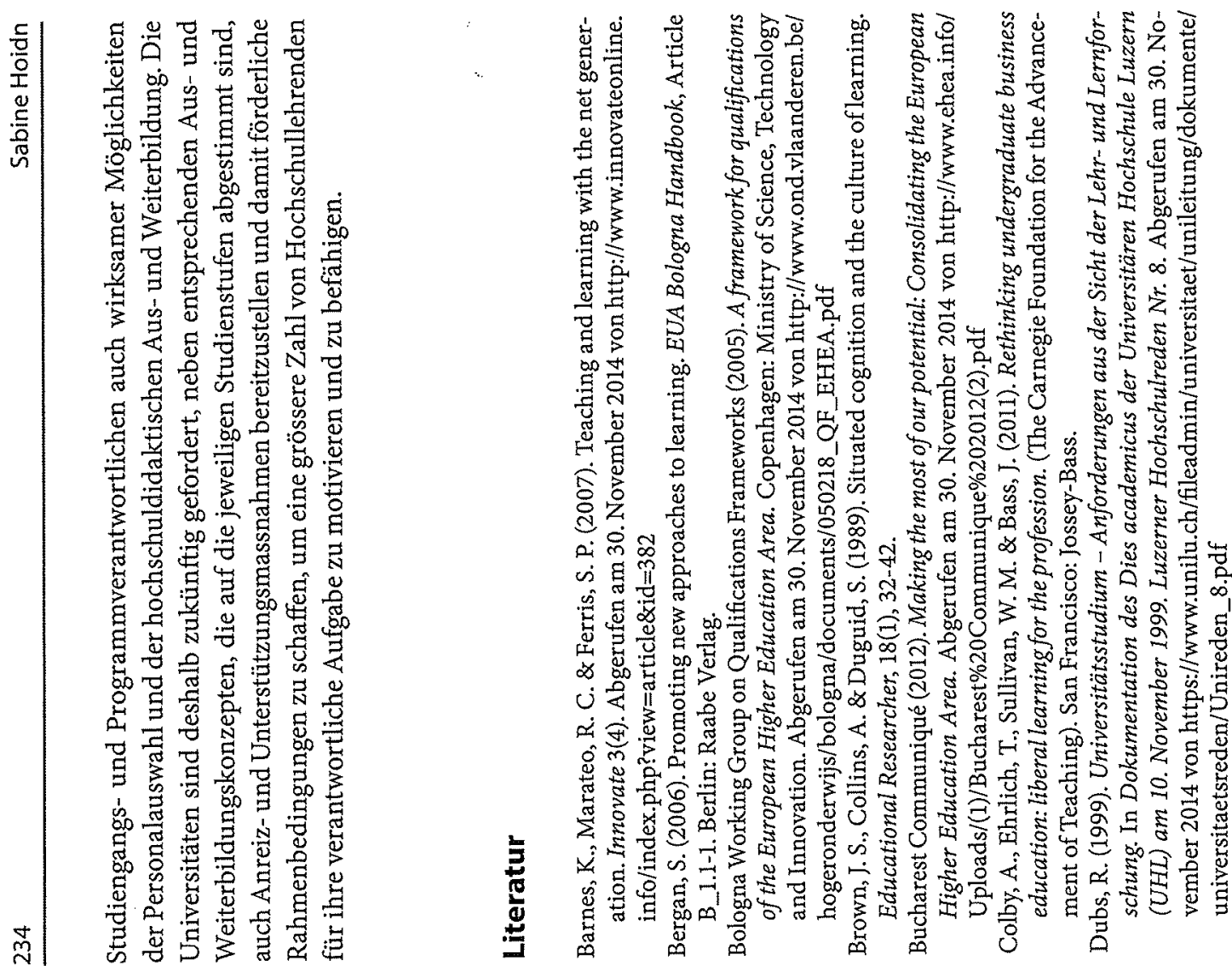

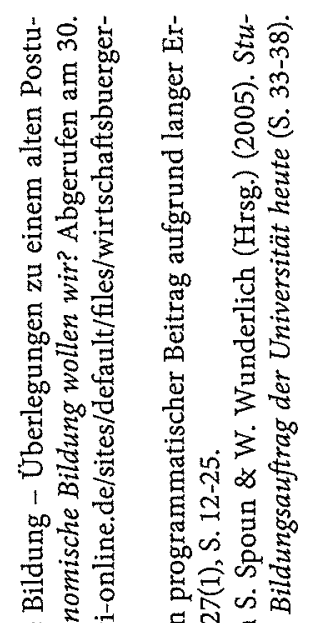

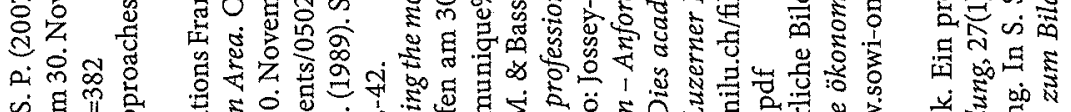

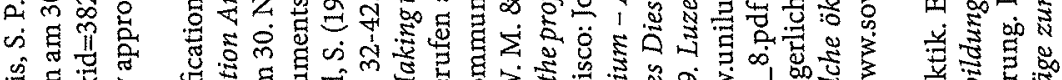

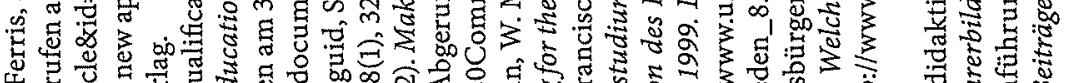

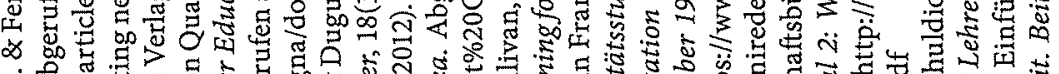

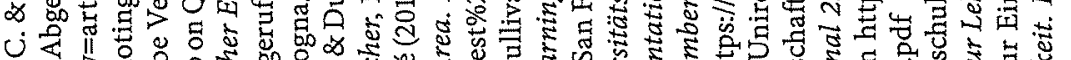

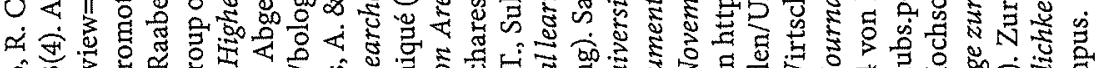

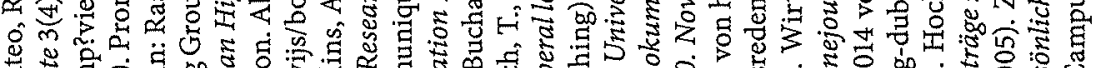

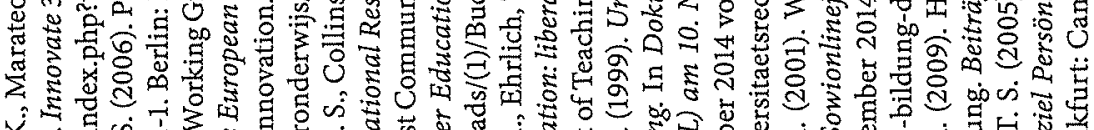

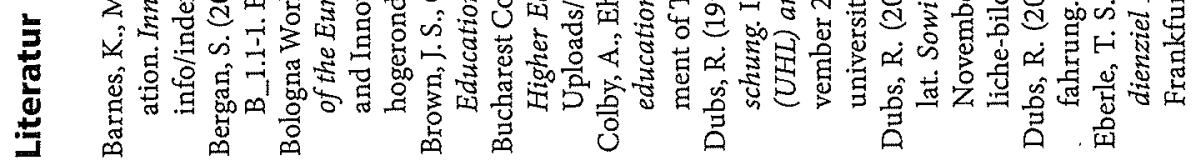

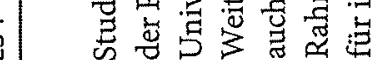




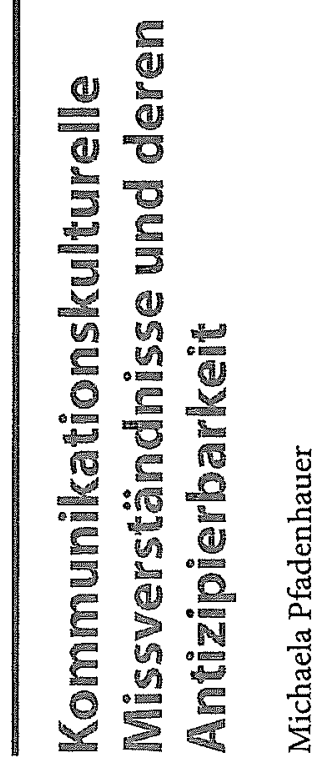

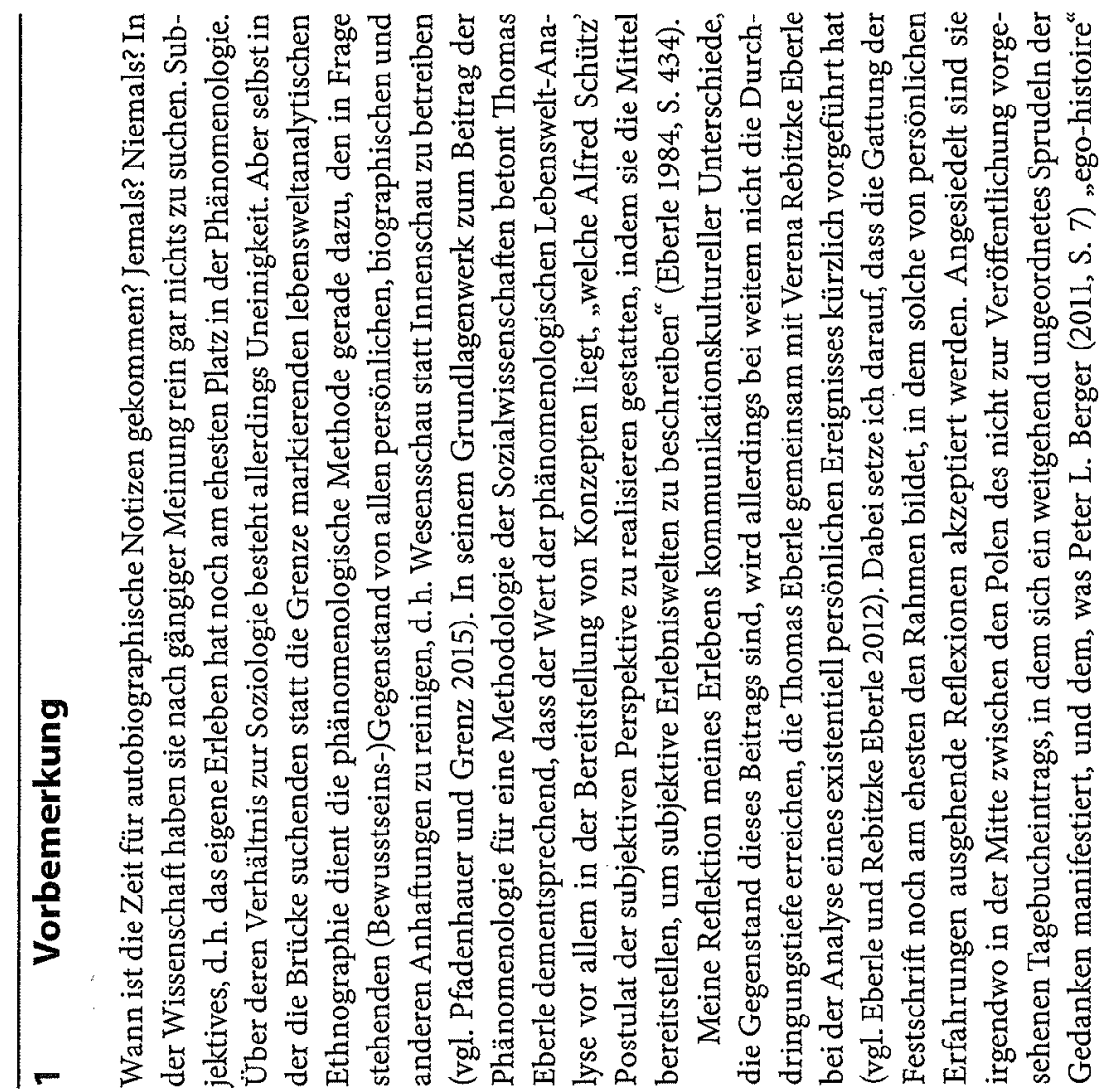

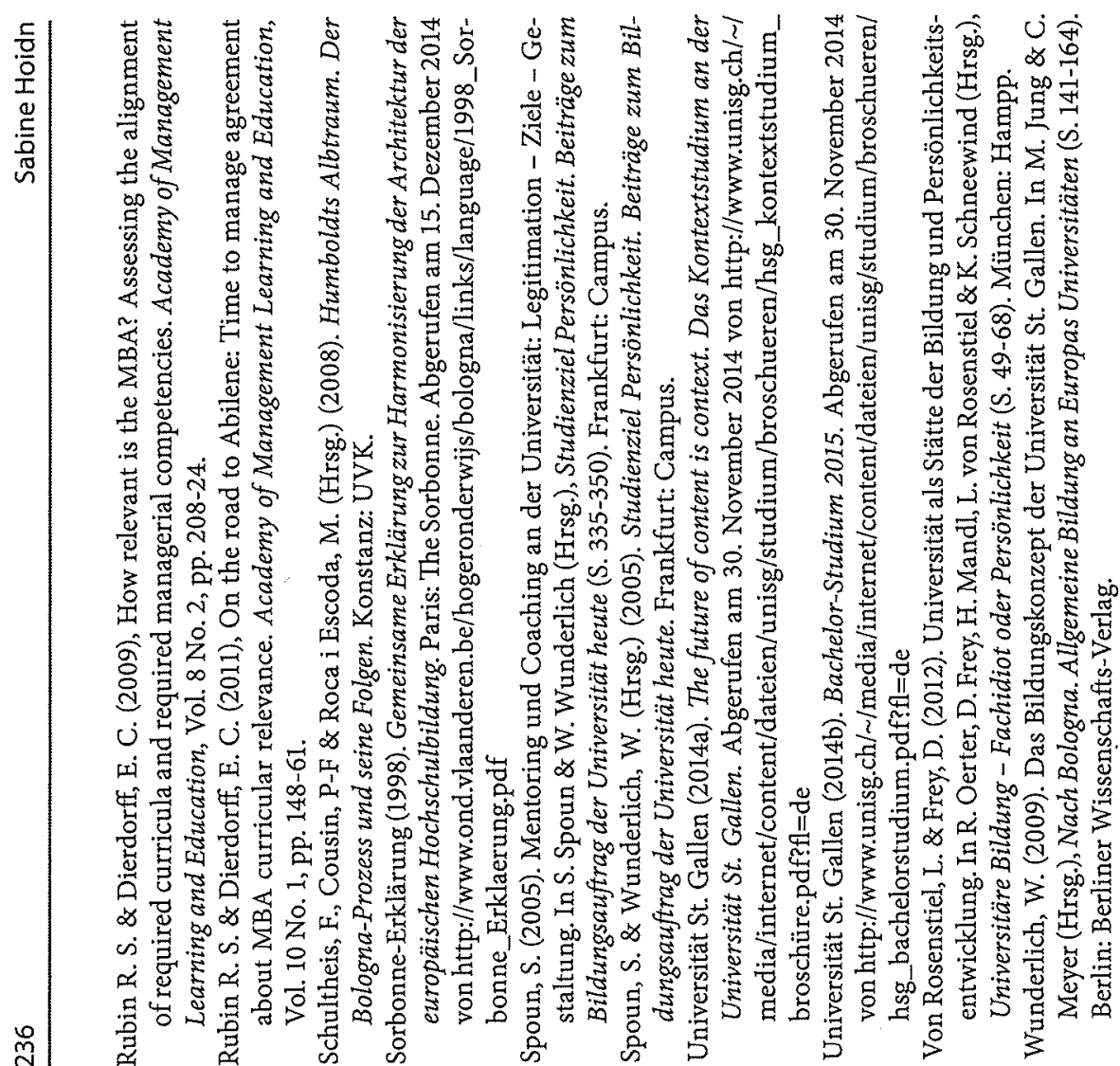

